\title{
VENTURE CAPITALISTS IN MATURE PUBLIC FIRMS
}

\author{
Ugur Celikyurt
}

A dissertation submitted to the faculty of the University of North Carolina at Chapel Hill in partial fulfillment of the requirements for the degree of Doctor of Philosophy in the KenanFlagler Business School (Finance).

Chapel Hill

2009

Approved by:

Anil Shivdasani

Paolo Fulghieri

Merih Sevilir

Matthias Kahl

Michael Roach 
(C)2009

Ugur Celikyurt

ALL RIGHTS RESERVED 


\section{ABSTRACT \\ Ugur Celikyurt: Venture Capitalists In Mature Public Firms \\ (Under the direction of Anil Shivdasani)}

By using an original hand-collected data on the professional backgrounds of board members of S\&P companies, this paper presents evidence on the role of venture capitalists (VCs) in mature public companies long time after their initial public offering (IPO). We find that $30.5 \%$ of S\&P firms, which have gone public almost 20 years ago, have at least one VC director on their board, suggesting that $\mathrm{VCs}^{\prime}$ governance role extends from newly public firms to mature public firms. VCs' presence as board members is not only limited to public firms which were VC-backed at the time of their IPO. 34.8\% of the firms with VC directors were not VC-backed at the time of their IPO. We find that firms with VC directors on board exhibit greater research and development (R\&D) and innovation activity measured by their patenting output. There is also a significant difference in the acquisition activity of firms with VC directors and firms with no VC directors. Firms with VC directors acquire smaller, more R\&D intensive and VC-backed targets. They also exhibit a greater amount of corporate venture capital (CVC) investment and form a greater number of joint ventures and strategic alliances with VC-backed firms than firms with no VC directors. Overall, this paper provides the first piece of evidence that, in addition to their role as providers of finance, monitoring and advice for small private firms, VCs also play a significant role in mature public firms, especially in promoting the R\&D and innovation activity in such firms. 


\section{ACKNOWLEDGEMENTS}

I would like to thank my advisor Anil Shivdasani for his thoughtful guidance and advice throughout this dissertation. I am also grateful to Paolo Fulghieri, Merih Sevilir, Matthias Kahl and Michael Roach for taking part in my dissertation committee, for critical reading of this dissertation and for their valuable suggestions and comments. Special thanks to Merih Sevilir for her insightful discussions and encouragements.

Finally, I would like to thank my family for giving me continuous moral support throughout my whole life. 


\section{TABLE OF CONTENTS}

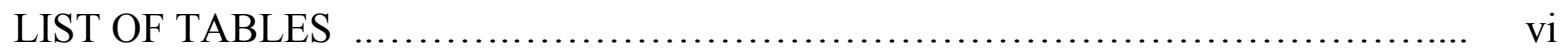

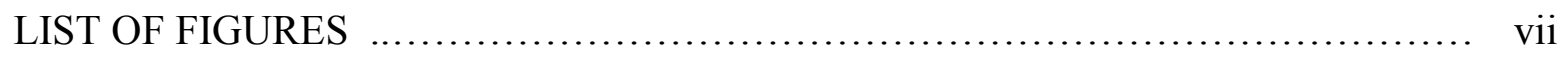

Chapter

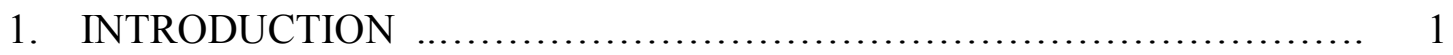

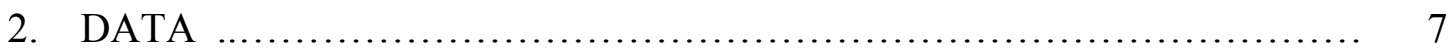

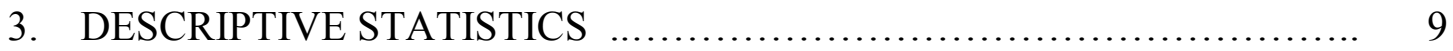

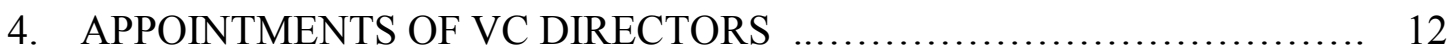

5. VC DIRECTORS AND PATENTING ACTIVITY ....................... 14

6. VC DIRECTORS AND ACQUISITION ACTIVITY .................... 17

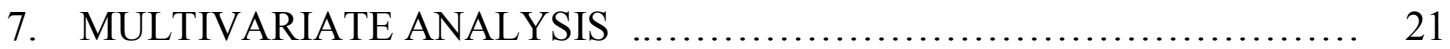

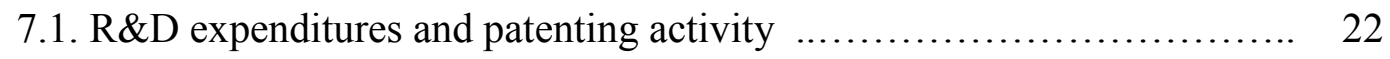

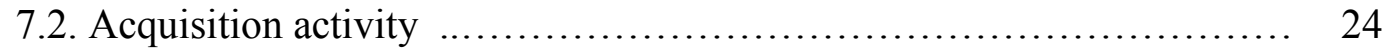

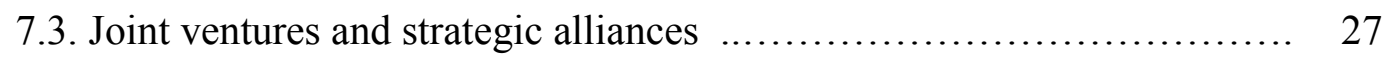

7.4. Determinants of $\mathrm{VC}$ director appointments and departures $\ldots \ldots \ldots \ldots \ldots .28$

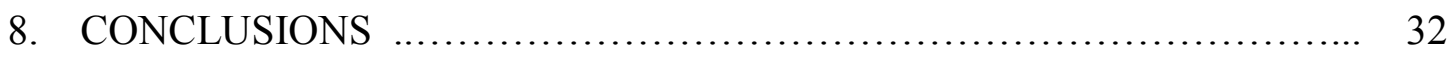

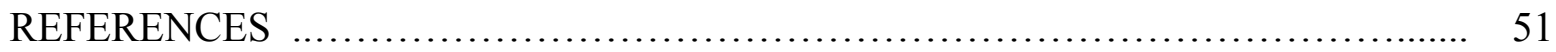




\section{LIST OF TABLES}

Table

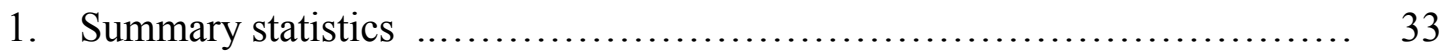

2. Acquisitions and partnerships around VC director appointments $\ldots \ldots \ldots \ldots . . . .36$

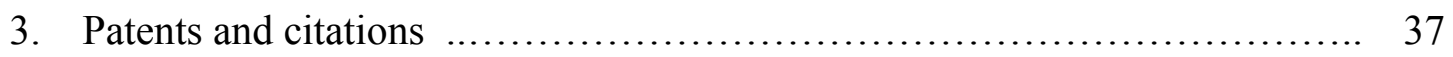

4. Acquisitions, corporate venture capital and strategic partnerships .......... 39

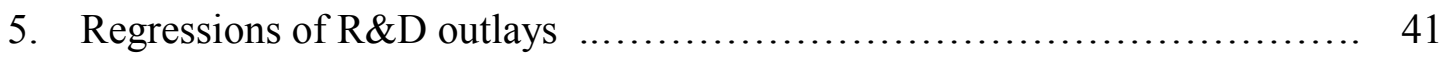

6. Determinants of the number of patents and citations $\ldots \ldots \ldots \ldots \ldots \ldots \ldots \ldots . \ldots 2$

7. Effect of VC directors on a public firm's acquisition strategy $\ldots \ldots \ldots \ldots \ldots . . . . .43$

8. Effect of VC directors on a public firm's strategic partnerships $\ldots \ldots \ldots \ldots \ldots . . \ldots 5$

9. Determinants of the VC director appointments and departures $\ldots \ldots \ldots \ldots \ldots . . \ldots 7$ 


\section{LIST OF FIGURES}

Figure

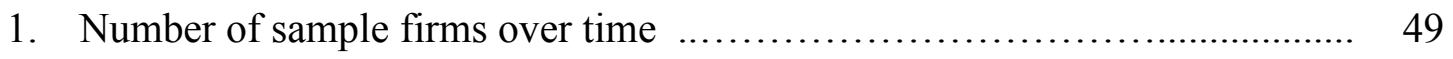

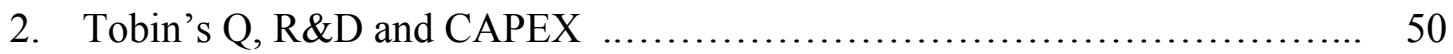




\section{CHAPTER 1}

\section{INTRODUCTION}

A broad literature documents the importance of venture capitalists (VCs) in the creation and growth of small and private entrepreneurial firms. VCs help their portfolio companies by providing advice and support (Gompers (1995) and Lerner (1995)), help with the professionalization of the management team (Hellmann and Puri (2002)), exercise monitoring and corporate governance (Hsu (2004), Kaplan and Stromberg (2003) and (2004), Lerner (1994), Lindsey (2008)), and foster innovation (Hellmann and Puri (2000) and Kortum and Lerner (2000)).

A more recent literature addresses VCs' role in public companies. Barry, Muscarella, Peavy and Vetsuypens (1990) find that IPO firms with higher quality VCs are less underpriced than IPO firms with lower quality VCs and argue this is due to monitoring and certification roles of higher quality VCs. Megginson and Weiss (1991) also document a negative relation between VC-backing and underpricing, further confirming the monitoring and certification roles of VCs. Baker and Gompers (2003) analyze the effect of VCs on board size and composition at the time of the IPO, and show that VC-backed companies have better performing boards of directors, and these boards are related to better long-run performance after the IPO. Brav and Gompers (1997) analyze the post-IPO performance of IPO firms and show that VC-backed firms do not tend to have negative performance after their IPOs. They 
also find that small firms with market capitalizations below $\$ 50$ million with no VC-backing have negative post-IPO performance. Hochberg (2006) studies the role of VC-backing on the corporate governance of the firm right after its IPO and finds that, compared to nonVCbacked firms, VC-backed firms have lower earnings management, experience a higher wealth effect on the announcement of poison pills, and have more independent boards of directors, audit committees and compensation committees. Although these papers focus on different dimensions of VCs' involvement in public companies, they all have one feature in common: They analyze the effects of VC involvement for only newly public firms around the IPO date. There has been no evidence so far on the presence of VCs in mature public companies beyond their IPO stage. This dissertation provides the first piece of evidence that, in addition to their role as providers of finance and advice for small and private firms, VCs play a significant role for mature public firms, even long time after the IPO stage, especially in promoting research and development $(\mathrm{R} \& \mathrm{D})$ and innovation activity. Our results show that firms with $\mathrm{VC}$ directors acquire more $\mathrm{R} \& \mathrm{D}$ intensive private firms, participate in a greater amount of corporate venture capital (CVC) investment in external start-ups, and form a greater number of joint ventures (JVs) and strategic alliances with VC-backed firms, providing a potential explanation for why such firms appear more innovative and R\&D intensive than firms without $\mathrm{VC}$ directors.

Using an original hand-collected dataset on the professional backgrounds of board members of S\&P500, S\&P MidCap and S\&P SmallCap companies, we classify directors into VC directors and non-VC directors based on whether a director has worked as a VC before his appointment as a director in a public firm. We find that $30.5 \%$ of the firms in our sample have at least one VC director on their board in the period from 1998 to 2006. Although firms 
which were VC-backed at the time of their IPO are more likely to have VCs on their board long time after going public, $34.8 \%$ of firms in our sample with VCs on board were not VCbacked at the time of their IPO.

To understand the mechanism through which VCs get appointed to the boards of mature public firms, we analyze a number of such firms in detail around the time of VC appointments as board members. The anecdotal evidence we find reveals an interesting pattern. It appears that one of the main channels through which mature public firms gain $\mathrm{VC}$ directors on their board is due to their acquisitions of VC-backed firms. As an example, consider the Andrew Corporation. This firm specializes in the design, manufacture and supply of communications systems as a public firm since its IPO in 1980. In 2002, it acquired the Celiant Corporation. Celiant was created in 2001 as an independent joint venture of Bell Labs and Lucent Technologies with the VC funding from Pequot Capital. With the VC investment, Gerald A. Poch, a managing director at Pequot became the chairman and a member of the board of Celiant. After Celiant was acquired by Andrew in 2002, Pequot became an investor in Andrew, and Gerald A. Poch joined Andrew's board of directors. ${ }^{1}$ Consistent with this example, our empirical test shows that a mature public firm is more likely to obtain a VC director on its board if this firm acquires a VC-backed target firm. ${ }^{2}$

Compared to firms with no VC directors, we find that firms with VC directors have more independent boards. VC directors are younger, more independent and less likely to be

\footnotetext{
${ }^{1}$ In the press release of Andrew Corp. on Feb 19, 2002, Mr. Poch said: "Strategically, we believe this merger will bring value to all parties and create new opportunities for Andrew to expand its reach within the wireless market. We are excited about being a long term investor in and advisor to Andrew."

${ }^{2}$ Another main channel through which mature public firms gain VC directors on their boards is simply the appointment of the $\mathrm{VC}$ directors to the board without their $\mathrm{VC}$ firm taking an equity ownership in these mature public firms. In these cases, the appointed VC directors' entrepreneurial experience is cited as the most important reason to elect them to the boards.
} 
insiders, and hold a lower percentage of outstanding shares than non-VC directors.

Furthermore, VC directors serve more on the audit, compensation, nominating and corporate governance committees than non-VC directors.

Firms with VC directors on board have significantly higher market-to-book ratios than firms without VC directors on board. The positive relation between the market-to-book ratio and the presence of $\mathrm{VCs}$ on boards becomes stronger as the number of $\mathrm{VC}$ directors on board increases. We also find that firms with VC directors on board exhibit greater R\&D and innovation output in terms of their patenting activity than firms without VC directors. In addition, the amount of R\&D outlays of a firm with $\mathrm{VC}$ directors increases monotonically in the number of VCs on board. In recent work, Lerner, Sorensen and Stromberg (2008) analyze the patenting activity of private firms that received private equity and show that private equity-backed firms have no decline in their patenting activity after they go private in an LBO. Our results on patenting activity of firms with VC directors complement their results by showing that the presence of $\mathrm{VC}$ directors is positively related to the number of patents obtained by our sample of public firms.

In addition to the differences in $R \& D$ outlays and patenting activity, we also document significant differences in the acquisition activity of firms with VC directors and firms without VC directors. As mentioned before, mature public firms are more likely to gain VC directors on their board as they acquire more VC-backed targets. It turns out that after gaining a $\mathrm{VC}$ director on their boards, these firms continue to exhibit a different acquisition behavior than firms with no VC directors. More specifically, they undertake a lower amount of acquisition activity than firms without VC directors. Furthermore, their acquisition targets are more likely to be smaller, private, more R\&D intensive and VC-backed than acquisition 
targets of firms with no VC directors. This finding suggests that firms with VC directors pursue acquisitions with a focus on their innovation output by acquiring $R \& D$ intensive firms and VC-backed firms. These firms also conduct less diversifying acquisitions than firms with no VC directors. Interestingly, firms with VC directors are more likely to acquire target firms which have VC directors on their board as well, suggesting that VCs may play a role in facilitating the acquisition of firms with $\mathrm{VC}$ involvement. An alternative explanation for this result could be that, as analyzed in Gompers and Xuan (2008), having a VC director in both firms may facilitate a merger between these two firms by reducing the asymmetric information about the values of these firms.

We also find that firms with VC directors engage in a greater amount of corporate venture capital (CVC) investment, where they acquire minority stakes in external entrepreneurial start-ups, compared to firms with no VC directors. Furthermore, they form a greater number of joint ventures with other VC-backed firms. Hence, our study suggests that having $\mathrm{VC}$ directors on board contributes to the $\mathrm{R} \& \mathrm{D}$ and innovation output of the firm by increasing the firm's investment in CVC and by facilitating strategic partnerships with other entrepreneurial firms.

Overall, this dissertation provides the first piece of evidence that VCs' role in financing and promoting innovation and entrepreneurial activity is not limited to small private firms only. VCs also serve on the boards of mature public firms and affect their R\&D and innovation activity as well as their acquisitions. Our results suggest that mature public firms with VC directors have a greater focus on internal growth through $\mathrm{R} \& \mathrm{D}$ and innovation activity than firms with no VC directors. They also prefer to undertake a lower amount of acquisition activity, and in their acquisitions, they are more likely to acquire private, R\&D 
intensive and VC-backed firms, and firms with VC directors on their board. Finally, even though firms with $\mathrm{VC}$ directors conduct a lower amount of acquisitions, they exhibit a greater amount of CVC investment and form a greater number of strategic relationships with VC-backed firms than firms without VC directors. Existing research on CVC (Chesbrough (2002), Dushnitsky and Lenox (2005) and (2006)) shows that CVC investment and strategic alliances, through which established firms undertake minority investments in small entrepreneurial start-ups, represent an important source of innovation for mature firms. Hence, our finding that firms with VC directors are more R\&D and innovation intensive than firms with no VC directors could be linked to their greater level of investment in CVC and strategic alliances.

Finally, our study is related to the recent literature which investigates the presence of different types of directors on corporate boards such as bankers, CEOs, and women. We contribute to this literature by showing the perhaps surprising prevalence of $\mathrm{VC}$ directors in mature public firms and extending the well-established governance role of VCs in small private firms to that in mature public firms.

The rest of this dissertation is organized as follows. Section 2 describes our sample, and Section 3 presents the descriptive statistics for board, director and firm characteristics. In Section 4, we analyze how VC directors get appointed to the boards of mature public firms in our sample. The patenting activity and the acquisition activity of our sample of firms are analyzed in Sections 5 and 6, respectively. Section 7 investigates the R\&D and patenting output, and acquisition, joint venture and strategic alliance activity of our sample of firms in a multivariate setting. Section 8 concludes. 


\section{CHAPTER 2}

\section{DATA}

Our director data comes from Investor Responsibility Research Center (IRRC). This database is of annual frequency and covers directors of S\&P 500, S\&P MidCap and S\&P SmallCap firms starting from 1996. The IRRC Directors database provides detailed information on the structure and practices of the boards of directors and also includes individual information for each director, such as their primary employment, the committees they serve on, their board affiliation, shares held and total voting power. Since IRRC starts to collect detailed data on the primary employment of board members from 1998 on, our sample covers public U.S. companies from 1998 to 2006.

There are a total of 2,325 unique firms and 21,888 unique directors covered in IRRC database from 1998 to 2006 . We exclude utility companies and financial companies from our sample since they operate in highly regulated industries. This restriction leaves us with a final sample of 1,839 firms and 16,911 directors, forming a panel dataset over nine years. ${ }^{1}$

We classify firms in the sample into two groups based on whether they have directors on board, who are partners or executives at venture capital (VC) firms (denoted by $V C$ directors), or not. In order to identify the VC directors, we employ a two-step search as follows: In the first step, we search for keywords, which might define a VC firm, in four

\footnotetext{
${ }^{1}$ This corresponds to 10,118 firm-years and 91,092 director-years.
} 
different data items provided by IRRC for each individual director. ${ }^{2}$ These data items are primary company name, primary employment category, other employment title and type of services. If at least one of these keywords is available in any of these data items, we record that director as a possible candidate for being an executive or a partner in a VC firm, i.e. a VC director, and his primary company as a possible candidate for being a VC firm. Using this initial search procedure, we were able to identify 4,828 firms as possible VC firms. In the second step, we hand-collect biographical information from proxy statements on those board members, who were identified as possible VC directors in the first step. Specifically, we check whether the primary companies they work for are indeed VC firms, and whether these directors are partners or executives at these VC firms. Using this second search procedure, we identified a total of 672 primary companies that are VC firms. ${ }^{3}$ We denote those directors who are partners or executives of a VC firm as VC directors and the others as non-VC directors. Firms with at least one VC director on board are classified as firms with $V C$ directors, whereas firms with no VC director on board are classified as firms with no VC directors.

Figure 1 shows the number of firms in our sample over the years, split into four groups according to the number of VC directors they have on their boards. In each year from 1998 to 2006 , on average $30.5 \%$ of the firms have at least one VC director on board.

\footnotetext{
${ }^{2}$ The keywords that we search for are: Venture, capital, partner, fund, investor, angel, private, equity, finance, financial, and management.

${ }^{3}$ This hand-collected data procedure reveals many small VC firms that cannot be identified using VentureXpert database. More specifically, 192 of the 672 primary companies that we identified as VC firms (i.e. $28.6 \%$ of the VC firms) do not have a record in the VentureXpert database since they are small firms.
} 


\section{CHAPTER 3}

\section{DESCRIPTIVE STATISTICS}

We first investigate whether characteristics of the firms that have VC directors on their board are different from characteristics of the firms that do not have VC directors on their board. Table 1 presents the comparisons of firm, board and director characteristics between firms with VC directors and firms with no VC directors.

Panel A of Table 1 reports descriptive statistics of the board characteristics for our sample of public firms. Out of 10,118 firm-year observations, 3,084 of them (i.e. 30.48\%) involve firms with $\mathrm{VC}$ directors on board and the remaining 7,034 (i.e. 69.52\%) involve firms with no VC directors on board. Both types of firms have almost the same board size with the average board size being nine. For firms with VC directors, the average number of VC directors on board is 1.35 , corresponding to $16.09 \%$ of the board size. Compared to firms with no VC directors, firms with VC directors have, on average, more independent boards with a lower percentage of inside directors (who are employees of the firms whose board they serve on) and a lower percentage of linked directors (who are directors having some sort of family or business ties to the firms whose board they serve on).

Panel B of Table 1 reports summary statistics for director characteristics. VC directors are on average more independent and less likely to be insiders than non-VC directors. They are younger, and they hold a lower percentage of outstanding shares than non-VC directors. 
Panel $\mathrm{C}$ of Table 1 shows the summary statistics for the committee membership characteristics of directors. We assign dummy variables taking the value of one if a director serves on the specified committee or is the chair of the specified committee and zero otherwise. We find that $\mathrm{VC}$ directors serve more on the audit, compensation, nominating and corporate governance committees, and they also chair more committees than non-VC directors. This finding is consistent with Hochberg (2008), which also documents that VCs serve on a greater number of committees in newly public firms.

In Panel D of Table 1, we report the descriptive statistics for the public firms in our sample. The financial data for our sample of firms comes from Compustat database. Firms with VC directors are on average younger, and they have been public for a shorter time period than firms with no VC directors. ${ }^{1}$ However, even if they are comparatively younger, a typical firm with VC directors is 25.38 years old and has been public for almost 20 years. The average market value of assets of firms with VC directors turns out to be $\$ 13,439.6$ million compared to $\$ 10,532.1$ million for firms with no VC directors, the difference being statistically significant. ${ }^{2}$

In Panel D of Table 1, we also examine whether firms with VC directors were VCbacked at the time of their IPO. We define a dummy variable which is equal to one for firms which were VC-backed at the time of their IPO, and zero otherwise. ${ }^{3}$ The mean of this dummy variable is 0.65 for firms with $\mathrm{VC}$ directors and 0.32 for firms with no VC directors,

\footnotetext{
${ }^{1}$ The founding dates are obtained from Jay R. Ritter's website, and the IPO dates come from SDC's New Issues database starting from 1970 on. For firms that went public before 1970, we take the first listing date in CRSP as the IPO date.

${ }^{2}$ The market value of assets is defined as total assets minus total equity plus market capitalization given by the number of shares outstanding times the share price.

${ }^{3}$ The data about whether firms were VC-backed at the time of their IPO comes from SDC's New Issues database and is reported in SDC starting from year 1970 on.
} 
indicating that a higher percentage of firms with VC directors were VC-backed at the time of their IPO compared to firms with no VC directors. We further find that $63.1 \%$ of the firms in our sample which were VC-backed at the time of their IPO have a VC director on board in at least one of the years from 1998 to 2006, whereas this percentage is $26.9 \%$ for firms which were not VC-backed at the time of their IPO. The correlation coefficient between being VCbacked at the time of the IPO and having a VC director on the board after the IPO turns out to be 0.36 and statistically significant at the $1 \%$ level.

Panel D of Table 1 also shows that firms with VC directors have higher Tobin's Q, and greater research and development (R\&D) expenditures, both in dollar terms and as a percentage of the firm's market value, compared to firms with no VC directors. The level of capital expenditures (CAPEX), however, is lower for firms with VC directors. Figure 2 shows how Tobin's Q, R\&D and CAPEX (both given as a percentage of the market value of the firm) change depending on the number of VC directors on board. We find that Tobin's Q and $\mathrm{R} \& \mathrm{D}$ increase monotonically with the number of $\mathrm{VC}$ directors on board, whereas CAPEX decreases monotonically with the number of VC directors on board. These results suggest that firms with VC directors are more research oriented and have more growth prospects. 


\section{CHAPTER 4}

\section{APPOINTMENTS OF VC DIRECTORS}

Even if the comparison of the firm characteristics between firms with VC directors and firms with no VC directors presented in Table 1 provides information about some major differences in these firms, this comparison on its own does not provide an answer about whether these characteristics play a role in determining the $\mathrm{VC}$ director appointments to the boards of the mature public firms in our sample. It is therefore necessary to analyze the VC director appointments in a multivariate setting, where we can assess the effect of each relevant firm characteristic on the appointment of a VC director more directly.

The anecdotal evidence given in the introduction about how VCs get appointed to the boards of mature public firms reveals that these firms gain VC directors on their board through the acquisition of VC-backed target firms. In order to test this hypothesis, we investigate the relationship between the appointment of a $\mathrm{VC}$ director to the boards of mature public firms and these firms' acquisitions of VC-backed targets around the VC director appointment, in a regression framework. Column (I) of Table 2 provides the estimates of the regression model, where the dependent variable is the percentage of the total acquisition volume invested in VC-backed targets in a given year and the independent variable of interest is a dummy variable that takes the value of one if the firm appoints at least one $\mathrm{VC}$ director to its board in that year and zero otherwise. We also include firm characteristics such as board size, number of independent directors on board, director ownership, firm size, firm 
public age, Tobin's Q, sales growth and leverage as control variables in the regression. The coefficient of the VC director appointment dummy turns out to be positive and statistically significant at the $1 \%$ level implying that the public firms in our sample undertake a greater volume of acquisitions of $\mathrm{VC}$-backed target firms around the time of a $\mathrm{VC}$ director appointment. This result is consistent with the view that acquisitions of VC-backed target firms represent an important channel through which VCs get appointed to the boards of acquiring public firms.

In addition to acquiring VC-backed targets, firms can also gain $\mathrm{VC}$ directors on their board through their strategic relationships with other firms. Columns (II) and (III) of Table 2 present the Poisson maximum likelihood estimates for the determinants of the number of joint ventures and strategic alliances formed by our sample of firms around VC director appointments. The coefficient of the $V C$ director appointment dummy turns out to be positive and statistically significant in both models, implying that the appointments of VC directors on the boards of mature public firms coincide with these firms forming joint ventures and strategic alliances with other firms. This result suggests that by broadening their network with other companies through joint ventures and strategic alliances, these public firms might increase their chance to appoint experienced VC directors to their boards who might be affiliated with the partner companies. 


\section{CHAPTER 5}

\section{VC DIRECTORS AND PATENTING ACTIVITY}

Even though R\&D expenditure is the most commonly used measure for a firm's potential for innovativeness, patents produced by a firm are shown to be a better measure for the research productivity of the firm compared to its R\&D outlays (Trajtenberg (1990) and Griliches (1990)). In this section, we analyze the patenting activity of our sample of firms and investigate whether the presence of $\mathrm{VC}$ directors on boards is related to the patenting activity of the firm.

The patent database, created by Hall, Jaffe and Trajtenberg (2001), comes from National Bureau of Economic Research (NBER). These data comprise detailed information on all U.S. patents granted between January 1963 and December 2002, all citations made to these patents between 1975 and 2002, and a broad match of patents to Compustat firms. ${ }^{1}$ Due to data limitations, we are able to analyze the innovation output of our sample of firms in terms of the patents they produce and the citations they receive only for the years from 1998 to 2002. It is important to note that NBER records a patent only after it is granted, i.e. after it is approved by United States Patent and Trademark Office (USPTO), which causes the patent data to suffer from a truncation problem. For example, we don't have data on most of the patents filed in 2001 and 2002 since the review process by the patent office takes on average two years, as reported in Hall, Jaffe and Trajtenberg (2001) and, as a result, these patents are

\footnotetext{
${ }^{1}$ The original work by Hall, Jaffe and Trajtenberg (2001) covers patent data until the end of year 1999, which is then extended by Bronwyn H. Hall until the end of year 2002.
} 
not very likely to be approved by the patent office till the end of 2002. We therefore conduct our analysis on patents for two alternative time periods, one from 1998 to 2000 and the other one from 1998 to 2002.

We analyze the number of patents produced by our sample of firms as a measure of their research productivity. However, the simple count of patents on its own is not a correct measure for the technological or economical significance of the patents. Trajtenberg (1990) and Hall, Jaffe and Trajtenberg (2005) document that patent citations are a good measure of the value of innovations since they show the cited patent's influence on further research activities and its economical significance. Therefore, in addition to the number of patents, we also investigate the number of citations received by our sample of firms on the patents they produce and the number of citations received per patent produced.

Panel A of Table 3 shows the summary statistics for the total number of patents produced by our sample of public firms that were eventually granted. For years from 1998 to 2000, where we have relatively more complete patent data, firms with VC directors produce more patents per year compared to firms with no VC directors. Once we pool these three years' patent data, we find that firms with $\mathrm{VC}$ directors produce approximately 69 patents per year compared to 48 patents per year for firms with no VC directors. Moreover, the median number of patents produced by these firms is thirteen for the former group and eight for the latter one, the difference being statistically significant at the $1 \%$ level.

Panel B of Table 3 shows the summary statistics for the total number of citations received by our sample of firms until year 2002 on all the patents they had produced in each year. For example, firms with VC directors received on average 131 citations until year 2002 on the patents they had produced in year 1998 whereas firms with no VC directors received 
on average 65 citations. Since a patent can receive a citation only after being approved by the patent office, the difference between the two groups of firms is more apparent for early years in the patent database where there is more time for the produced patent to receive future citations. Once we pool the first three years' citation data, we find that firms with $\mathrm{VC}$ directors received approximately 61 citations compared to 40 citations for firms with no VC directors. The median number of citations received by these firms is six for the former group and four for the latter one, the difference being statistically significant at the $10 \%$ level.

Panel $\mathrm{C}$ of Table 3 presents summary statistics for the total number of patents, citations and citations per patent as a function of the number of VC directors on board. We find that firms with three or more VC directors on board produce a higher number of patents and receive a higher number of citations on average than firms with no $\mathrm{VC}$ directors on board, with the difference being statistically significant at the $1 \%$ level. Firms with three or more $\mathrm{VC}$ directors also receive a greater number of citations per patent than firms with no VC directors on board. Among the firms with at least one VC director on board, firms with three or more VC directors have the highest number of patents, the highest number of citations and also the highest number of citations per patent suggesting that the impact of an additional VC director on a firm's research productivity is increasing in the number of VC directors on board. These results show that firms with VC directors on board are not only more innovative in terms of their patenting ability but they also have more influential and economically significant innovations as measured by the number of citations they receive per patent. 


\section{CHAPTER 6}

\section{VC DIRECTORS AND ACQUISITION ACTIVITY}

In order to investigate whether our finding that firms with VC directors are more R\&D intensive and innovative could be explained by these firms acquiring more R\&D intensive and VC-backed targets, or these firms establishing joint ventures (JVs) and strategic alliances with other R\&D intensive and VC-backed firms, in this section, we analyze how the presence of VC directors on board affects a firm's acquisitions, corporate venture capital (CVC) investments, JVs and strategic alliances.

Data on acquisition activity comes from Securities Data Company (SDC)'s Mergers and Acquisitions (M\&A) database. We include only completed deals and exclude buybacks, exchange offers and recapitalizations from the M\&A data. Data on JVs and strategic alliances also comes from SDC's M\&A database, and the data on CVC comes from SDC VentureXpert database. There are a total of 9,436 M\&A transactions, 3,306 CVC rounds, 1,395 joint ventures and 6,637 strategic alliances, in which our sample of firms participated from 1998 to 2006.

Panel A of Table 4 shows that the total acquisition volume as a percentage of the

firm's market value of assets is lower for firms with VC directors compared to firms with no VC directors. Firms with VC directors also differ from firms with no VC directors in terms of their acquisition patterns. More specifically, firms with VC directors undertake smaller and more focused acquisitions, pay more with stock than cash and are more likely to acquire 
private firms compared to firms with no VC directors. Among firms which conduct an acquisition, firms with $\mathrm{VC}$ directors invest on average $31.06 \%$ of their total acquisition volume in VC-backed targets, whereas firms with no VC directors invest only half of this amount (16.57\%) in VC-backed targets, suggesting that the higher R\&D intensity and innovation activity of firms with VC directors compared to firms with no VC directors could be due to these firms acquiring more VC-backed target firms, which are innovative firms.

We also explore in more detail how VC directors may affect the acquisition behavior of the firms, whose board they serve on. It could be that they facilitate the acquisition of other VC-backed firms through their contacts and business links with VCs in potential target firms. While the board of director data is available for all the acquiring firms, there is much less information about boards of the target firms. The reason is that only 1,272 transactions (i.e. $13.48 \%$ of all the M\&A transactions from 1998 to 2006) involve a public target firm, for which IRRC data might be available. ${ }^{1}$ We are able to identify the target firms' boards for 144 transactions, 56 of which involve acquiring firms with $\mathrm{VC}$ directors on board and 88 of which involve acquiring firms with no VC directors on board. We find that $48.21 \%$ of the firms with VC directors acquired targets with at least one $\mathrm{VC}$ director on board whereas this percentage decreases to $20.45 \%$ for firms with no VC directors. We find a positive correlation of 0.29 between having a $\mathrm{VC}$ director on board in the acquiring firm and having a VC director on board in the target firm, which is statistically significant at the $1 \%$ level. This finding suggests that the presence of a VC director on board may facilitate the acquisition of firms with VC involvement. This result is similar to the finding in Gompers and Xuan (2008) that an acquisition is more likely to take place when there is a common $\mathrm{VC}$ investor in the

\footnotetext{
${ }^{1}$ Other frequencies for the public status of the target firms are: Private $(4,943)$, subsidiary $(3,024)$, joint venture (187) and government (10).
} 
acquiring and the target firm, establishing a bridge between the two firms and reducing the asymmetric information in the transaction.

Gompers and Xuan (2008) define a public firm as VC-backed if that firm was VCbacked at the time of its IPO. Our definition differs considerably from theirs in that they have a static definition for VC-backed public firms, whereas we define firms with VC directors dynamically over time. That is, since we can keep track of the public firms' boards over time, we are able to identify which firms have VC directors and which firms do not, at each point in time. As we mentioned before, $36.9 \%$ of the mature public firms in our sample, which were VC-backed at the time of their IPO, do not have VC directors in any of the years in our sample time period, whereas $26.9 \%$ of the firms, which were not VC-backed at the time of their IPO, gain VC directors long time after their IPO in the sample period. Therefore, being VC-backed at the time of the IPO does not necessarily correspond to having a VC involvement in later years. Our finding shows that even if there is a positive correlation between a firm being VC-backed at the time of its IPO and having a VC director later in its public life, our definition leads to a more precise classification of mature public firms with respect to their relations to VCs.

There is a growing literature on the use of CVC to promote innovation output of mature established firms. While firms with $\mathrm{VC}$ directors have a lower acquisition activity than firms with no VC directors, it could be that these firms prefer to grow through minority acquisitions by undertaking CVC investment in entrepreneurial start-ups. It is also possible that firms with VC directors substitute majority acquisitions with smaller minority acquisitions especially given the evidence that that acquiring firms do not gain from acquisitions when they undertake majority acquisitions. Therefore, firms with VC directors 
can use $\mathrm{CVC}$ as an alternative way to invest in other companies by taking minority equity positions. Panel B of Table 4 shows that firms with VC directors provide $\mathrm{CVC}$ to a higher number of portfolio companies, invest a larger amount of CVC (normalized by firm size) in these portfolio companies, and have a larger amount of total CVC under management than firms with no VC directors, all differences being significant at the $1 \%$ level. This result shows that CVC investments might substitute for acquisitions in firms with VC directors, and these investments might be one of the channels through which the innovation output of these firms with VC directors is increasing.

In addition to helping public firms, whose board they serve on, acquire VC-backed targets and provide CVC to entrepreneurial start-ups, VC directors could also be facilitating contacts or strategic links and alliances between these public firms and other VC-backed or R\&D intensive firms. In fact, consistent with this view, Lindsey (2008) shows that VCbacked private firms are more likely to form a strategic alliance if they share the same VC. We explore a similar possibility for our sample of mature firms by investigating whether having a VC director on board is positively related to the firm establishing strategic alliances and joint ventures with other firms. VC directors could be influential or key in making such transactions possible by using their network of contacts and relationships with other VCs. Panel $\mathrm{C}$ of Table 4 shows that firms with VC directors form a higher number of strategic alliances with other companies than firms with no VC directors. 


\section{CHAPTER 7}

\section{MULTIVARIATE ANALYSIS}

In order to test whether our univariate results hold in a multivariate setting after controlling for firm characteristics, which have shown to be important determinants of R\&D and acquisition volume, we conduct fixed effects regressions of R\&D outlays and the acquisition volume for our sample of public firms. We use Poisson maximum likelihood models to verify our results on the number of patents and citations obtained by our sample of firms and our results on the number of joint ventures and strategic alliances formed by them. Logit models are employed for binary dependent variables such as a dummy variable indicating whether a firm in our sample acquires a VC-backed target or not.

In most of the models that we employ, we have four primary variables of interest which measure VC directorship on boards. More specifically, we define three dummy variables to describe firms with $\mathrm{VC}$ directors on their board. $\mathrm{VCl}$ is a dummy variable that takes the value of one if the firm has one $\mathrm{VC}$ director on board and zero otherwise. $V C 2$ takes the value of one if the firm has two VC directors on board and zero otherwise, and finally $V C 3$ takes the value of one if the firm has three or more VC directors on board and zero otherwise. The fourth primary variable is the number of VC directors on board. ${ }^{1}$

The main control variables that we include in our models are the number of independent directors on board, director ownership defined as the proportion of outstanding

\footnotetext{
${ }^{1} \mathrm{We}$ use the number of $\mathrm{VC}$ directors on board rather than the proportion of $\mathrm{VC}$ directors on board in the multivariate models in order to provide easy comparison with our univariate results. However, our multivariate results are robust to alternative definitions of the $\mathrm{VC}$ director-related variables.
} 
shares owned by all directors of the firm, firm size defined as the natural logarithm of the market value of assets, Tobin's $Q$ given by the ratio of the market value of assets to the book value of assets, leverage defined as interest bearing debt divided by operating assets, and firm public age given by the natural logarithm of the number of years since the firm's IPO. All of our models include firm and/or industry fixed effects and year dummies as well to control for unobservable attributes. Finally, to correct for heteroskedasticity and correlation of errors within firms, we cluster standard errors at the firm level.

\section{1. $\quad R \& D$ expenditures and patenting activity}

Our first set of regressions involves panel data estimates relating the $R \& D$ outlays (normalized by firm size) to VC directors on board and other firm characteristics that might play a role in explaining the $R \& D$ expenditures of firms. Table 5 presents the results. Model (I) shows that the coefficients for $V C l$ and $V C 2$ are positive and statistically significant at the $5 \%$ level. In model (II), we use the number of VC directors on board as our main variable of interest and find a positive and significant coefficient on this variable as well. Therefore, both specifications indicate a positive and statistically significant relation between the number of VC directors and the firm's R\&D outlays, even after controlling for firm fixed effects. R\&D expenditures are also positively related to the number of independent directors on board. These results suggest that the presence of VC human capital in mature public firms has a positive effect on the R\&D activity of the firm. Our finding on the positive relation between the number of VC directors and R\&D activity remains robust after controlling for industry fixed effects in addition to firm fixed effects. Models (III) and (IV) in Table 5 show the results under these alternative specifications. 
Our univariate results have shown that firms with $\mathrm{VC}$ directors are more innovative as measured by their patenting activity than firms with no VC directors. The greater R\&D intensity in firms with VC directors documented here might explain their higher innovation output. We test this relationship in a multivariate setting, where we estimate Poisson maximum likelihood models to investigate the determinants of the number of patents, the number of citations and the number of citations per patent obtained by our sample of firms.

To eliminate the truncation problem related to patents and citations mentioned before, the patent related variables are adjusted for industry and year effects before running the regressions. More specifically, the number of patents is adjusted by dividing the number of patents of a firm by the mean number of patents in the same cohort to which the patent belongs, where the cohorts are constructed for each year and technology class defined by United States Patent and Trademark Office (USPTO). ${ }^{2}$ Similar adjustments are made for the number of citations and the number of citations per patent as well. The adjusted numbers are then rounded to the nearest integer to be used as the dependent variables in the Poisson models.

Table 6 presents the estimates for the Poisson maximum likelihood models of the patenting activity for our sample of firms. As expected, the coefficient of the R\&D intensity is positive and statistically significant in determining the number of patents, citations and citations per patent obtained by the sample firms. The number of $\mathrm{VC}$ directors on itself does not seem to affect a firm's patenting activity. However, its interactions with R\&D intensity and firm public age turn out to be significant in determining the patenting activity. More specifically, the coefficient of the interaction term between the number of VC directors and

\footnotetext{
${ }^{2}$ The technology classes defined by USPTO are: Computers and communications, drugs and medical, electrical and electronics, chemical, mechanical and others.
} 
the R\&D intensity is positive and significant in determining the number of citations per patent, suggesting that the positive effect of $\mathrm{R} \& \mathrm{D}$ on the technological or economical significance of the patents (given by citations per patent) is stronger in firms with VC directors on board compared to firms with no VC directors on board.

Results in Table 6 also show that younger firms are more active in patenting activity compared to older firms. However, once we interact the firm public age with the number of VC directors, we find that the relationship between the firm public age and the firm's patenting activity reverses its sign with the sample firms obtaining more patents and citations as they get older if they have more VC directors on board. Overall, our results on the patenting output suggest that the presence of VC directors is positively related to the firm's innovation activity. Hence, our results complement the finding in Kortum and Lerner (2000) that increases in venture capital activity in an industry are associated with significantly higher patenting rates. While Kortum and Lerner (2000) look at VC funding in private firms in an industry, our results are complementary in that we obtain a similar finding regarding the positive effect of VCs on innovation output for public firms.

\subsection{Acquisition activity}

Having documented that firms with VC directors are more R\&D intensive and innovative in terms of their patenting activity, we now turn our attention to whether these firms keep their R\&D and innovation focus when they undertake acquisitions. It could be that firms with VC directors pursue acquisitions with a focus on their innovation output by acquiring R\&D intensive firms and VC-backed firms. In this section, we address this question by examining whether having a VC director on board affects the types of acquisitions the firm undertakes. 
We first run panel data regressions which relate the acquisition volume (normalized by size) by our sample of firms to the number of $\mathrm{VC}$ directors on board and other firm characteristics that might have an effect on acquisitions. Table 7 presents the results. Model (I) shows that the coefficients for $V C 2$ and $V C 3$ are negative and statistically significant at the $5 \%$ and $1 \%$ level, respectively. In model (II), we use the number of VC directors on board as our main variable of interest and find a negative and significant coefficient on this variable as well. Therefore, both specifications indicate a negative and statistically significant relation between the number of VC directors and the firm's acquisition volume even after controlling for firm fixed effects. We obtain nearly the same results after controlling for industry fixed effects in addition to firm fixed effects. Columns (III) and (IV) in Table 7 present the estimates for this case. These results verify our univariate finding that firms with VC directors undertake less acquisitions compared to firms with no VC directors.

We further explore whether the differences shown in the univariate analysis between firms with VC directors and firms with no VC directors in terms of their acquisition patterns still hold in a multivariate framework. We run regressions with the percentage of the total acquisition volume invested by the firm in the given type of acquisition as the dependent variable. Columns from (V) to (VII) in Table 7 present the results. Column (V) shows that firms with VC directors invest a higher percentage of their total acquisition volume in VCbacked targets compared to firms with no VC directors on board, and Column (VI) shows that firms with $\mathrm{VC}$ directors invest a higher percentage of their total acquisition volume in private targets. Hence, supporting our univariate results, we find that firms with VC directors are more likely to acquire private and VC-backed targets than firms without VC directors. ${ }^{3}$

\footnotetext{
${ }^{3}$ The data about the venture capital imbursements to target firms comes from SDC's VentureXpert database.
} 
Our finding that firms with $\mathrm{VC}$ directors invest a higher percentage of their total acquisition volume in VC-backed targets does not provide information about the likelihood of these firms to acquire VC-backed firms in the first place. We therefore estimate logit models for the probability of a mature public firm in our sample to acquire a VC-backed target, where the dependent variable takes the value of one if the target firm is VC-backed and zero otherwise. Columns (VIII) and (IX) in Table 7 present the results. The coefficients of the VC indicators and the coefficient of the number of VC directors turn out to be positive and statistically significant implying that having VC directors on boards is positively related to the firm's likelihood of acquiring VC-backed target firms.

In order to verify that the targets acquired by the firms in our sample are also more R\&D intensive, we estimate a fixed effects regression using the target firm's R\&D expenditure normalized by its size as the dependent variable. ${ }^{4}$ Model (X) of Table 7 shows the results. In addition to the usual control variables, we also include the acquiring firm's R\&D expenditure normalized by its size as an explanatory variable. We find that firms with a higher number of $\mathrm{VC}$ directors and higher R\&D outlays acquire target firms which are more R\&D intensive as well. Moreover, younger firms which have gone public more recently are also more likely to acquire $R \& D$ intensive targets. These findings are consistent with our earlier results that the presence of VC human capital in mature public firms affects their R\&D intensity positively which, in turn, positively affects the innovation activity and innovation output of such firms.

Overall, our results in this section support the view that firms with VC directors exhibit a greater focus on R\&D and innovation by acquiring more VC-backed firms and

\footnotetext{
${ }^{4}$ The sample size in model (X) of Table 7 drops considerably compared to models (V) through (VII) since we are able to find the target firm's R\&D only if it is public and available in the Compustat database.
} 
firms with higher R\&D intensity compared to firms with no VC directors. These results are consistent with the idea that having VC directors on board affects a firm's acquisition strategy, i.e. the type of the acquisitions it undertakes, and such firms set their acquisition strategy with a focus on their R\&D and innovation output.

\subsection{Joint ventures and strategic alliances}

A growing literature in financial economics studies strategic alliances and joint ventures, where two firms join forces for technological advancement or to improve their innovation prospects. Lindsey (2008) studies strategic alliances between U.S. firms and documents that VC-backed firms are more likely to form a strategic alliance if they share the same venture capital investor. Robinson and Stuart (2007) examine strategic alliances in the biotechnology industry and document that when two firms are closely linked in the alliance network, their deal is less likely to involve equity participation and more likely to involve funding pledges from clients. Both of these studies emphasize the positive effect of networking on establishing strategic relationships among firms. Following a similar logic, the relationships of VC directors with each other and with the public firms involved may play a role in initiating strategic relationships and investments with other VC-backed and innovation oriented firms. Hence, in this section, we investigate whether having VC directors on board is positively related to the firms' strategic alliance and joint venture activities.

Columns (I) through (IV) in Table 8 present the estimates for the Poisson maximum likelihood models of the number of joint ventures (JVs) and the number of strategic alliances formed by our sample of firms. Models (I) and (II) have the number of JVs as the dependent variable, and models (III) and (IV) have the number of strategic alliances as the dependent variable. We include the usual control variables and firm fixed effects in these models. The 
coefficients of the VC director indicators and the coefficient of the number of VC directors turn out to be positive and statistically significant, both for JV and alliance models. This result suggests that firms with a greater number of $\mathrm{VC}$ directors engage in a greater number of JVs and strategic alliances, thereby providing support for the $\mathrm{VC}$ directors' role as a facilitator for strategic relationships with other firms.

The innovation focus of the public firms with VC directors can be more directly tested by exploring whether these firms are more likely to start partnerships with other VCbacked firms in joint ventures (JVs) and strategic alliances compared to firms with no VC directors. ${ }^{5}$ In models (V) through (VII) of Table 8, we estimate logit models for the probability of a firm in our sample to form JVs and strategic alliances with VC-backed companies. In models (V) and (VI), the dependent variable takes the value of one if the partner firm in the JV is VC-backed and zero otherwise, and in model (VII) the dependent variable takes the value of one if the partner firm in the alliance is VC-backed and zero otherwise. The coefficients of the VC indicators and the coefficient of the number of VC directors turn out to be positive and significant in JV models implying that the higher the number of $\mathrm{VC}$ directors on board the higher the likelihood of the firm to form a joint venture with a VC-backed firm rather than a nonVC-backed firm. For alliances, however, we don't find a significant effect of VC directors on alliances with VC-backed firms.

Overall, our results on JVs and strategic alliances suggest that the VC directors play a significant role in expanding the investment opportunity set of the firms they oversee and also in facilitating strategic relationships of these firms with other entrepreneurial VC-backed firms.

\subsection{Determinants of $\mathrm{VC}$ director appointments and departures}

${ }^{5}$ The data about the venture capital imbursements to partner firms comes from SDC's VentureXpert database. 
Our results so far have shown that after controlling for firm, industry and year fixed effects, firms with VC directors spend more on R\&D, are more likely to acquire VC-backed and R\&D intensive firms, and are more likely to form strategic relationships with other VCbacked firms in the form of strategic alliances and joint ventures. One key concern about these results could be that the causality may be in the reverse direction. In other words, it could be that innovative and R\&D intensive firms, which acquire VC-backed targets and which form strategic relationships with VC-backed firms, are more likely to gain VC directors on their boards as a result of their transactions with these VC-backed firms, rather than the VC directors making the public firms, whose boards they serve on, more innovative and $R \& D$ intensive.

In this section, we address this potential endogeneity of $\mathrm{VC}$ directors with respect to R\&D, acquisitions of VC-backed targets, and JVs and alliances established with VC-backed targets. We study an alternative case that might also lead to a positive relation between VC directors and R\&D expenditures, between VC directors and VC-backed target acquisition activity, and between VC directors and the number of JVs and alliances with VC-backed firms. More specifically, we explore whether firms are more likely to appoint VC directors on their board when they are more $R \& D$ intensive, when they acquire a greater number of VC-backed targets, and when they form a greater number of JVs and strategic alliances with VC-backed firms. It is also possible that the VCs are attracted to these firms perhaps because they can learn from the innovation capability of these firms.

We estimate logit models to investigate the determinants of $\mathrm{VC}$ director appointments and $\mathrm{VC}$ director departures. We control for firm characteristics as well as director related characteristics in our models, and use their one-year lagged values as explanatory variables. 
The variables of interest are the firm's R\&D (normalized by its size), the acquisition volume it invests in VC-backed targets (normalized by its size), and its number of JVs and alliances with VC-backed firms. The results are reported in Table 9. Columns (I) and (II) present the results for the $\mathrm{VC}$ director appointments, where the dependent variable takes the value of one if at least one VC director is appointed to the board and zero otherwise, with model (I) including industry fixed effects and model (II) including firm fixed effects. Similarly, columns (III) and (IV) present the results for the VC director departures, where the dependent variable takes the value of one if a VC director departs from the board and zero otherwise, with model (III) including industry fixed effects and model (IV) including firm fixed effects.

Model (I) in Table 9 shows that a firm's R\&D is positively related to the probability of appointing a $\mathrm{VC}$ director, whereas the acquisition volume it invests in $\mathrm{VC}$-backed targets and the number of its JVs and alliances with VC-backed firms are unrelated to VC director appointment. Once we account for firm fixed effects in model (II), the significance of R\&D disappears as well leaving only the director's age and the number of directorships he or she holds as the only factors affecting the appointment of a $\mathrm{VC}$ director. These results on the $\mathrm{VC}$ director appointment do not support the alternative view that innovative and $R \& D$ intensive firms are more likely to gain VC directors on their boards. The results in this section rather support our findings so far that the VC directors make the public firms, whose boards they serve on, more innovative and $\mathrm{R} \& \mathrm{D}$ intensive.

Model (III) in Table 9 shows that a firm's R\&D is also positively related to the probability of a VC director to depart. The acquisition volume a firm invests in VC-backed targets turns out to positively affect the VC director departure as well, whereas the number of 
JVs and the number of alliances with VC-backed firms are unrelated to VC director departure. Model (IV) of VC director departure with firm fixed effects causes R\&D and the acquisition volume invested in VC-backed targets to lose their significance, while the number of the alliances with VC-backed firms comes out to positively affect a VC director's departure. These findings about the VC director departure work against the alternative view's conjecture that innovative and $\mathrm{R} \& \mathrm{D}$ intensive firms are more likely to gain $\mathrm{VC}$ directors on their boards, since more R\&D, a greater investment in VC-backed targets and a greater number of alliances with VC-backed firms lead to a VC director departure rather than a VC director appointment.

Overall, we find that a firm's R\&D, its acquisition volume invested in VC-backed targets, and the number of its JVs and alliances with VC-backed firms do not play a role in determining a VC director appointment. This finding suggests that our documented results so far on the positive relation between VC directors and the firm's R\&D, its acquisition volume of VC-backed targets and the number of its JVs and alliances with VC-backed firms is robust to the potential endogeneity of VC directors. 


\section{CHAPTER 8}

\section{CONCLUSIONS}

This dissertation provides the first piece of evidence that VCs play an important role in mature public firms long time after their IPO. This result is novel since the existing literature on venture capital so far has mainly concentrated on different roles VCs play for small and private companies. Our study complements the existing work by documenting that VCs add value to mature public companies past their IPO stage. More specifically, our study shows that VCs serve on the boards of mature public firms, and firms with VC directors exhibit a greater amount of $R \& D$ and innovation output in terms of their patenting activity. Firms with VC directors are more likely to acquire private, R\&D intensive and VC-backed firms, and more likely to establish business relationships with other VC-backed firms in the form of strategic alliances and joint ventures. In addition, such firms exhibit a greater amount of corporate venture capital investment in VC-backed entrepreneurial start-ups.

Overall, this dissertation suggests that, in addition to their role as providers of finance and advice for small and private firms, VCs play a significant role for mature public firms, even long time after the IPO stage, especially in promoting R\&D and innovation activity in such firms. 


\section{Table 1. Summary statistics}

This table presents the descriptive statistics of board, director and firm characteristics for IRRC firms between 1998 and 2006 . Panel A presents the descriptive board statistics of our sample. VC directors are directors serving on public firms' boards who are actually executives or partners of venture capital firms. Inside directors are employees of the firms whose board they serve on. Linked directors are directors having some sort of family or business ties to the firms whose board they serve on. Busy directors are directors who serve on three or more boards. Panel B and Panel C present the descriptive statistics of director characteristics for IRRC firms. Panel B reports the statistics for dummy variables taking the value of 1 if a director belongs to the specified category and 0 otherwise. Panel $\mathrm{C}$ reports the statistics for dummy variables taking the value of 1 if a director serves on the specified committee or is the chair of the specified committee and 0 otherwise. Panel D presents the descriptive firm statistics of our sample of IRRC firms. Firm age is defined as the number of years since the firm's foundation. "VC-backed at the time of IPO" is a dummy variable which takes the value of 1 if the firm is VC-backed at the time of the IPO and 0 otherwise. The market value of assets (MVA) is defined as total assets minus total equity plus market capitalization given by the number of shares outstanding times the share price. Tobin's $\mathrm{Q}$ is the ratio of market value of assets to book value of assets. ***, **, and * indicate statistical significance at the $1 \%, 5 \%$ and $10 \%$ level, respectively.

\begin{tabular}{|c|c|c|c|c|c|c|c|c|c|c|c|}
\hline \multicolumn{12}{|c|}{ Panel A: Descriptive Board Statistics } \\
\hline & \multicolumn{3}{|c|}{ Overall sample } & \multicolumn{3}{|c|}{$\begin{array}{l}\text { Firms with at least one VC } \\
\text { director on board }\end{array}$} & \multicolumn{3}{|c|}{$\begin{array}{l}\text { Firms with no VC director } \\
\text { on board }\end{array}$} & \multicolumn{2}{|c|}{$\begin{array}{l}\text { Comparison between VC- } \\
\text { and nonVC-board firms }\end{array}$} \\
\hline & $\mathrm{N}$ & Mean & Median & $\mathrm{N}$ & Mean & Median & $\mathrm{N}$ & Mean & Median & t-statistics & z-statistics \\
\hline Board size & 10118 & 9.00 & 9 & 3084 & 9.03 & 9 & 7034 & 8.99 & 9 & 0.85 & 0.01 \\
\hline Number of VC directors & 10118 & 0.41 & 0 & 3084 & 1.35 & 1 & 7034 & 0.00 & 0 & & \\
\hline Percentage of VC directors & 10118 & 4.91 & 0 & 3084 & 16.09 & 12.5 & 7034 & 0.00 & 0 & & \\
\hline $\begin{array}{l}\text { Percentage of independent } \\
\text { directors }\end{array}$ & 10118 & 66.01 & 66.67 & 3084 & 68.19 & 71.43 & 7034 & 65.05 & 66.67 & $8.75^{* * *}$ & $8.34 * * *$ \\
\hline Percentage of inside directors & 10118 & 20.68 & 16.67 & 3084 & 19.21 & 16.67 & 7034 & 21.32 & 18.18 & $-9.31 * * *$ & $-7.34 * * *$ \\
\hline Percentage of linked directors & 10118 & 13.29 & 11.11 & 3084 & 12.59 & 11.11 & 7034 & 13.60 & 11.11 & $-3.43 * * *$ & $-3.85 * * *$ \\
\hline Percentage of busy directors & 10118 & 23.00 & 20.00 & 3084 & 26.47 & 25.00 & 7034 & 21.48 & 16.67 & $11.44 * * *$ & $12.41 * * *$ \\
\hline $\begin{array}{l}\text { Percentage of shares held by all } \\
\text { directors and officers }\end{array}$ & 10118 & 11.39 & 5.70 & 3084 & 9.64 & 4.90 & 7034 & 12.16 & 6.10 & $-8.42 * * *$ & $-7.27 * * *$ \\
\hline $\begin{array}{l}\text { Percentage of shares held by all } \\
\text { directors }\end{array}$ & 10104 & 9.89 & 3.97 & 3078 & 8.16 & 3.35 & 7026 & 10.65 & 4.32 & $-6.77 * * *$ & $-6.96 * * *$ \\
\hline $\begin{array}{l}\text { Average percentage of shares } \\
\text { held by each director }\end{array}$ & 10104 & 1.20 & 0.48 & 3078 & 0.97 & 0.41 & 7026 & 1.30 & 0.51 & $-8.30 * * *$ & $-6.62 * * *$ \\
\hline $\begin{array}{l}\text { Percentage of votes held by all } \\
\text { directors }\end{array}$ & 10115 & 10.39 & 2.90 & 3083 & 8.37 & 2.30 & 7032 & 11.27 & 3.30 & $-7.15 * * *$ & $-7.51 * * *$ \\
\hline
\end{tabular}


Panel B: Descriptive Director Statistics

\begin{tabular}{|c|c|c|c|c|c|c|c|c|c|c|c|}
\hline & \multicolumn{3}{|c|}{ Overall sample } & \multicolumn{3}{|c|}{ VC directors } & \multicolumn{3}{|c|}{ Non-VC directors } & \multicolumn{2}{|c|}{$\begin{array}{l}\text { Comparison between VC } \\
\text { and non-VC directors }\end{array}$} \\
\hline & $\mathrm{N}$ & Mean & Median & $\mathrm{N}$ & Mean & Median & $\mathrm{N}$ & Mean & Median & t-statistics & z-statistics \\
\hline VC director (indicator) & 91092 & 0.05 & 0.00 & 4166 & 1 & 1 & 86926 & 0 & 0 & & \\
\hline Independent director (indicator) & 91092 & 0.66 & 1 & 4166 & 0.82 & 1 & 86926 & 0.66 & 1 & $26.61^{* * *}$ & $21.89^{* * *}$ \\
\hline Inside director (indicator) & 91092 & 0.20 & 0 & 4166 & 0.04 & 0 & 86926 & 0.21 & 0 & $-50.28 * * *$ & $-26.44 * * *$ \\
\hline Linked director (indicator) & 91092 & 0.14 & 0 & 4166 & 0.14 & 0 & 86926 & 0.14 & 0 & 0.74 & 0.74 \\
\hline Number of other boards served & 91046 & 0.91 & 0 & 4163 & 1.28 & 1 & 86883 & 0.90 & 0 & $17.29^{* * *}$ & $20.95^{* * *}$ \\
\hline Percentage of shares held & 90994 & 1.10 & 0.06 & 4155 & 0.61 & 0.07 & 86839 & 1.12 & 0.05 & $-10.07 * * *$ & $1.76^{*}$ \\
\hline Director age & 91071 & 59.14 & 59 & 4166 & 57.02 & 57 & 86905 & 59.24 & 59 & $-16.05^{* * *}$ & $-15.28^{* * *}$ \\
\hline
\end{tabular}

\begin{tabular}{|c|c|c|c|c|c|c|c|c|c|c|c|}
\hline & \multicolumn{3}{|c|}{ Overall sample } & \multicolumn{3}{|c|}{$\mathrm{VC}$ directors } & \multicolumn{3}{|c|}{ Non-VC directors } & \multicolumn{2}{|c|}{$\begin{array}{l}\text { Comparison between VC } \\
\text { and non-VC directors }\end{array}$} \\
\hline & $\mathrm{N}$ & Mean & Median & $\mathrm{N}$ & Mean & Median & $\mathrm{N}$ & Mean & Median & t-statistics & z-statistics \\
\hline \multirow{2}{*}{$\begin{array}{l}\text { Audit committee member } \\
\text { Compensation committee } \\
\text { member }\end{array}$} & 91092 & 0.40 & 0 & 4166 & 0.50 & 0 & 86926 & 0.39 & 0 & $13.14^{* * *}$ & $13.40^{* * *}$ \\
\hline & 91092 & 0.38 & 0 & 4166 & 0.52 & 1 & 86926 & 0.38 & 0 & $17.83^{* * *}$ & $18.30^{* * *}$ \\
\hline \multirow{2}{*}{$\begin{array}{l}\text { Nominating committee member } \\
\text { Corporate governance } \\
\text { committee member }\end{array}$} & 91092 & 0.33 & 0 & 4166 & 0.37 & 0 & 86926 & 0.33 & 0 & $6.14 * * *$ & $6.32 * * *$ \\
\hline & 91092 & 0.25 & 0 & 4166 & 0.28 & 0 & 86926 & 0.25 & 0 & $5.31 * * *$ & $5.53 * * *$ \\
\hline Audit committee chair & 91092 & 0.08 & 0 & 4166 & 0.10 & 0 & 86926 & 0.08 & 0 & $4.43 * * *$ & $4.89 * * *$ \\
\hline Compensation committee chair & 91092 & 0.08 & 0 & 4166 & 0.11 & 0 & 86926 & 0.08 & 0 & $7.72 * * *$ & $9.13 * * *$ \\
\hline
\end{tabular}




\begin{tabular}{|c|c|c|c|c|c|c|c|c|c|c|c|}
\hline \multicolumn{12}{|c|}{ Panel D: Descriptive Firm Statistics } \\
\hline & \multicolumn{3}{|c|}{ Overall Sample } & \multicolumn{3}{|c|}{$\begin{array}{c}\text { Firms with at least one VC } \\
\text { director on board }\end{array}$} & \multicolumn{3}{|c|}{$\begin{array}{l}\text { Firms with no VC director on } \\
\text { board }\end{array}$} & \multicolumn{2}{|c|}{$\begin{array}{l}\text { Comparison between VC- } \\
\text { and nonVC-board firms }\end{array}$} \\
\hline & $\mathrm{N}$ & Mean & Median & $\mathrm{N}$ & Mean & Median & $\mathrm{N}$ & Mean & Median & $\mathrm{t}$-statistics & Z-statistics \\
\hline Firm age & 3971 & 31.33 & 23 & 1566 & 25.38 & 19 & 2405 & 35.21 & 26 & $-13.62 * * *$ & $-16.28 * * *$ \\
\hline $\begin{array}{l}\text { Number of years since the } \\
\text { firm went public }\end{array}$ & 9250 & 22.81 & 17 & 2841 & 19.40 & 13 & 6409 & 24.32 & 19 & $-12.29 * * *$ & $-15.30 * * *$ \\
\hline $\begin{array}{l}\text { Market value of assets } \\
\text { (MVA) (\$ millions) }\end{array}$ & 8519 & 11417.1 & 2202.5 & 2593 & 13439.6 & 2816.6 & 5926 & 10532.1 & 1984.0 & $3.10 * * *$ & $9.21 * * *$ \\
\hline $\begin{array}{l}\text { VC-backed at the time of } \\
\text { the IPO (indicator) }\end{array}$ & 4608 & 0.45 & 0 & 1768 & 0.65 & 1 & 2840 & 0.32 & 0 & $23.26 * * *$ & $22.01 * * *$ \\
\hline Tobin's Q & 8519 & 2.14 & 1.66 & 2593 & 2.47 & 1.88 & 5926 & 2.00 & 1.58 & $11.13 * * *$ & $13.67 * * *$ \\
\hline $\begin{array}{l}\text { R\&D expense } \\
\text { (\$ millions) }\end{array}$ & 8526 & 143.17 & 5.50 & 2596 & 191.13 & 23.81 & 5930 & 122.18 & 0.47 & $4.65 * * *$ & $16.57 * * *$ \\
\hline $\begin{array}{l}\text { R\&D expense (as a } \\
\text { percentage of MVA) }\end{array}$ & 8512 & 1.68 & 0.32 & 2593 & 2.41 & 1.15 & 5919 & 1.36 & 0.03 & $13.09 * * *$ & $16.00 * * *$ \\
\hline $\begin{array}{l}\text { CAPEX ( } \$ \text { millions) } \\
\text { CAPEX (as a percentage }\end{array}$ & 8455 & 299.68 & 54.66 & 2573 & 295.26 & 55.70 & 5882 & 301.62 & 54.09 & -0.23 & 0.88 \\
\hline of MVA) & 8444 & 3.36 & 2.27 & 2570 & 2.80 & 1.82 & 5874 & 3.60 & 2.48 & $-10.21 * * *$ & $-12.80 * * *$ \\
\hline
\end{tabular}




\section{Table 2. Acquisitions and partnerships around VC director appointments}

This table shows the regression results of the percentage of the total acquisition volume invested in VCbacked targets in column (I), Poisson maximum likelihood estimates for the determinants of the number of joint ventures (JVs) and strategic alliances formed by our sample of firms in column (II) and Poisson maximum likelihood estimates for the determinants of the number of strategic alliances in column (III). $V C$ director appointment is a dummy variable that takes the value of 1 if the firm appoints at least one VC director to its board and 0 if any director other than a $\mathrm{VC}$ is appointed to the board. Board size gives the number of directors serving on the board, Director ownership is the proportion of shares owned by all directors of the firm, Firm size is the natural logarithm of market value of assets, Tobin's $Q$ is the lagged ratio of market value of assets to book value of assets, Leverage is defined as interest bearing debt divided by operating assets, Sales growth is the difference between the current sales and the lagged sales normalized by lagged sales, and Firm public age is the natural logarithm of the number of years since the firm's IPO. The regressions also include a constant term and year dummies which are not reported. Industry dummies are assigned according to the Fama-French 48 industry groups. For each independent variable, the first row reports its estimated coefficient and the second row the corresponding t-statistic or z-statistic. All standard errors are heteroskedasticity-robust and are clustered at the firm level. ***,**, and * indicate statistical significance at the $1 \%, 5 \%$ and $10 \%$ level, respectively.

\begin{tabular}{|c|c|c|c|}
\hline & $\begin{array}{l}\text { VC-backed } \\
\text { target }\end{array}$ & $\begin{array}{l}\text { Number of JVs and } \\
\text { Strategic Alliances }\end{array}$ & $\begin{array}{l}\text { Number of } \\
\text { Strategic Alliances }\end{array}$ \\
\hline & (I) & (II) & (III) \\
\hline \multirow[t]{2}{*}{ VC director appointment (indicator) } & 15.848 & 0.225 & 0.306 \\
\hline & $2.63 * * *$ & $1.75^{*}$ & $2.35 * *$ \\
\hline \multirow[t]{2}{*}{ Number of independent directors } & 1.137 & 0.071 & 0.084 \\
\hline & 1.56 & $3.30 * * *$ & $3.46^{* * *}$ \\
\hline \multirow[t]{2}{*}{ Board size } & -22.675 & -0.957 & -1.140 \\
\hline & $-2.99 * * *$ & $-3.69 * * *$ & $-4.07 * * *$ \\
\hline \multirow[t]{2}{*}{ Director ownership } & -5.282 & -0.295 & -0.348 \\
\hline & -0.94 & -1.18 & -1.2 \\
\hline \multirow[t]{2}{*}{ Firm size } & 2.970 & 0.732 & 0.730 \\
\hline & $3.15^{* * *}$ & $23.05 * * *$ & $21.42 * * *$ \\
\hline \multirow[t]{2}{*}{ Tobin's Q } & 2.189 & -0.067 & -0.059 \\
\hline & $2.33 * *$ & $-4.46^{* * *}$ & $-4.00 * * *$ \\
\hline \multirow[t]{2}{*}{ Leverage } & -7.829 & -0.240 & -0.205 \\
\hline & -1.38 & $-3.84 * * *$ & $-2.79 * * *$ \\
\hline \multirow[t]{2}{*}{ Sales growth } & -4.881 & -0.582 & -0.683 \\
\hline & -1.21 & $-3.7 * * *$ & $-3.75 * * *$ \\
\hline \multirow[t]{2}{*}{ Firm public age } & -1.590 & -0.065 & -0.083 \\
\hline & -0.94 & -1.46 & $-1.7 *$ \\
\hline Industry Fixed Effects & Yes & Yes & Yes \\
\hline Year Dummies & Yes & Yes & Yes \\
\hline Adjusted $\mathrm{R}^{2} /$ Pseudo $\mathrm{R}^{2}$ & 0.1325 & 0.5075 & 0.5100 \\
\hline Sample Size & 1211 & 3661 & 3661 \\
\hline
\end{tabular}




\section{Table 3. Patents and citations}

This table presents the descriptive statistics for the innovative activity of the firms in our sample. Panel A reports the statistics for the patents produced and eventually granted, and Panel B reports the citations received by those patents. Panel C reports the pooled results for the patents, citations and citations per patent as a function of the number of $\mathrm{VC}$ directors on board. ***, **, and * indicate statistical significance at the $1 \%, 5 \%$ and $10 \%$ level, respectively.

\begin{tabular}{|c|c|c|c|c|c|c|c|c|c|c|c|}
\hline \multicolumn{12}{|c|}{ Panel A: Number of patents produced by a firm that are eventually granted } \\
\hline & \multicolumn{3}{|c|}{ Overall sample } & \multicolumn{3}{|c|}{$\begin{array}{c}\text { Firms with at least one VC } \\
\text { director on board }\end{array}$} & \multicolumn{3}{|c|}{$\begin{array}{c}\text { Firms with no VC director on } \\
\text { board }\end{array}$} & \multicolumn{2}{|c|}{$\begin{array}{l}\text { Comparison between VC- } \\
\text { and nonVC-board firms }\end{array}$} \\
\hline & $\mathrm{N}$ & Mean & Median & $\mathrm{N}$ & Mean & Median & $\mathrm{N}$ & Mean & Median & t-statistics & Z-statistics \\
\hline 1998 & 348 & 59.53 & 9 & 100 & 89.86 & 12 & 248 & 47.29 & 9 & & \\
\hline 1999 & 319 & 53.70 & 9 & 101 & 67.38 & 12 & 218 & 47.37 & 8 & & \\
\hline 2000 & 271 & 48.71 & 8 & 91 & 48.92 & 13 & 180 & 48.60 & 6 & & \\
\hline 2001 & 214 & 20.86 & 5 & 77 & 19.68 & 6 & 137 & 21.52 & 4 & & \\
\hline 2002 & 61 & 3.39 & 2 & 20 & 2.70 & 2 & 41 & 3.73 & 2 & & \\
\hline $1998-2000$ & 938 & 54.42 & 9 & 292 & 69.33 & 13 & 646 & 47.68 & 8 & 1.27 & $3.25 * * *$ \\
\hline \multirow[t]{4}{*}{ 1998-2002 } & 1213 & 45.93 & 7 & 389 & 56.07 & 10 & 824 & 41.15 & 6 & 1.15 & $3.14 * * *$ \\
\hline & \multicolumn{11}{|c|}{ Panel B: Number of citations received by a firm until 2002 on all the patents it has produced } \\
\hline & \multicolumn{3}{|c|}{ Overall sample } & \multicolumn{3}{|c|}{$\begin{array}{c}\text { Firms with at least one VC } \\
\text { director on board }\end{array}$} & \multicolumn{3}{|c|}{$\begin{array}{c}\text { Firms with no VC director on } \\
\text { board }\end{array}$} & \multicolumn{2}{|c|}{$\begin{array}{l}\text { Comparison between VC- } \\
\text { and nonVC-board firms }\end{array}$} \\
\hline & $\mathrm{N}$ & Mean & Median & $\mathrm{N}$ & Mean & Median & $\mathrm{N}$ & Mean & Median & t-statistics & z-statistics \\
\hline 1998 & 348 & 84.04 & 9 & 100 & 130.95 & 12 & 248 & 65.12 & 8 & & \\
\hline 1999 & 319 & 35.69 & 5 & 101 & 38.43 & 6 & 218 & 34.42 & 4 & & \\
\hline 2000 & 271 & 10.98 & 1 & 91 & 9.57 & 2 & 180 & 11.69 & 1 & & \\
\hline 2001 & 214 & 0.88 & 0 & 77 & 0.56 & 0 & 137 & 1.06 & 0 & & \\
\hline 2002 & 61 & 0.02 & 0 & 20 & 0.00 & 0 & 41 & 0.02 & 0 & & \\
\hline $1998-2000$ & 938 & 46.49 & 4 & 292 & 61.12 & 6 & 646 & 39.87 & 4 & 1.02 & $1.72 *$ \\
\hline $1998-2002$ & 1213 & 36.10 & 2 & 389 & 45.99 & 2 & 824 & 31.44 & 2 & 0.92 & 0.66 \\
\hline
\end{tabular}




\begin{tabular}{|c|c|c|c|c|c|c|c|c|c|c|c|c|c|c|}
\hline \multicolumn{15}{|c|}{ Panel C: Number of patents, citations and citations per patent as a function of the number of VCs on board } \\
\hline & \multicolumn{3}{|c|}{$\begin{array}{c}\text { Firms with no VC on } \\
\text { board }\end{array}$} & \multicolumn{3}{|c|}{$\begin{array}{c}\text { Firms with } 1 \mathrm{VC} \text { on } \\
\text { board }\end{array}$} & \multicolumn{3}{|c|}{$\begin{array}{c}\text { Firms with } 2 \text { VCs on } \\
\text { board }\end{array}$} & \multicolumn{3}{|c|}{$\begin{array}{c}\text { Firms with } 3 \text { or more } \\
\text { VCs on board }\end{array}$} & \multicolumn{2}{|c|}{$\begin{array}{c}\text { Comparison between } \\
\text { firms with } 3 \text { or more } \\
\text { VCs on board and } \\
\text { firms with no VC on } \\
\text { board } \\
\end{array}$} \\
\hline & $\mathrm{N}$ & Mean & Median & $\mathrm{N}$ & Mean & Median & $\mathrm{N}$ & Mean & Median & $\mathrm{N}$ & Mean & Median & $\begin{array}{r}\mathrm{t}- \\
\text { statistics } \\
\end{array}$ & $\begin{array}{r}\mathrm{Z}- \\
\text { statistics } \\
\end{array}$ \\
\hline Patents 1998-2000 & 646 & 47.68 & 8 & 208 & 71.86 & 11 & 58 & 58.43 & 12 & 26 & 73.35 & 27 & 0.90 & $3.14 * * *$ \\
\hline Patents 1998-2002 & 824 & 41.15 & 6 & 282 & 57.55 & 9.5 & 75 & 47.23 & 7 & 32 & 63.81 & 26 & 0.97 & $3.29 * * *$ \\
\hline Citations $1998-2000$ & 646 & 39.87 & 4 & 208 & 62.46 & 5 & 58 & 49.36 & 6 & 26 & 76.65 & 14 & 1.11 & $2.99 * * *$ \\
\hline Citations 1998-2002 & 824 & 31.44 & 2 & 282 & 46.20 & 1 & 75 & 38.21 & 2 & 32 & 62.41 & 9 & 1.17 & $2.90 * * *$ \\
\hline $\begin{array}{r}\text { Citations per patent } \\
1998-2000\end{array}$ & 646 & 0.69 & 0.47 & 208 & 0.55 & 0.37 & 58 & 0.57 & 0.33 & 26 & 0.86 & 0.67 & 0.96 & $1.66^{*}$ \\
\hline $\begin{array}{r}\text { Citations per patent } \\
1998-2002\end{array}$ & 824 & 0.55 & 0.22 & 282 & 0.41 & 0.16 & 75 & 0.45 & 0.17 & 32 & 0.70 & 0.43 & 1.05 & $1.85^{*}$ \\
\hline
\end{tabular}


Table 4. Acquisitions, corporate venture capital and strategic partnerships

This table presents the summary statistics for the M\&A transactions, CVC investments, joint ventures and strategic alliances conducted by our sample of firms between 1998 and 2006. Panel A reports the volume of different types of acquisitions as a percentage of total acquisition volume. Relative deal size is calculated for each acquisition and is defined as the transaction value as a percentage of the acquiring firm's size. Panel B shows the number and volume of the corporate venture capital (CVC) investments of the sample firms. Panel $\mathrm{C}$ presents the number of joint ventures and strategic alliances formed by the sample firms. The market value of assets (MVA) is defined as total assets minus total equity plus market capitalization given by the number of shares outstanding times the share price. ${ }^{* *},{ }^{* *}$, and $*$ indicate statistical significance at the $1 \%, 5 \%$ and $10 \%$ level, respectively.

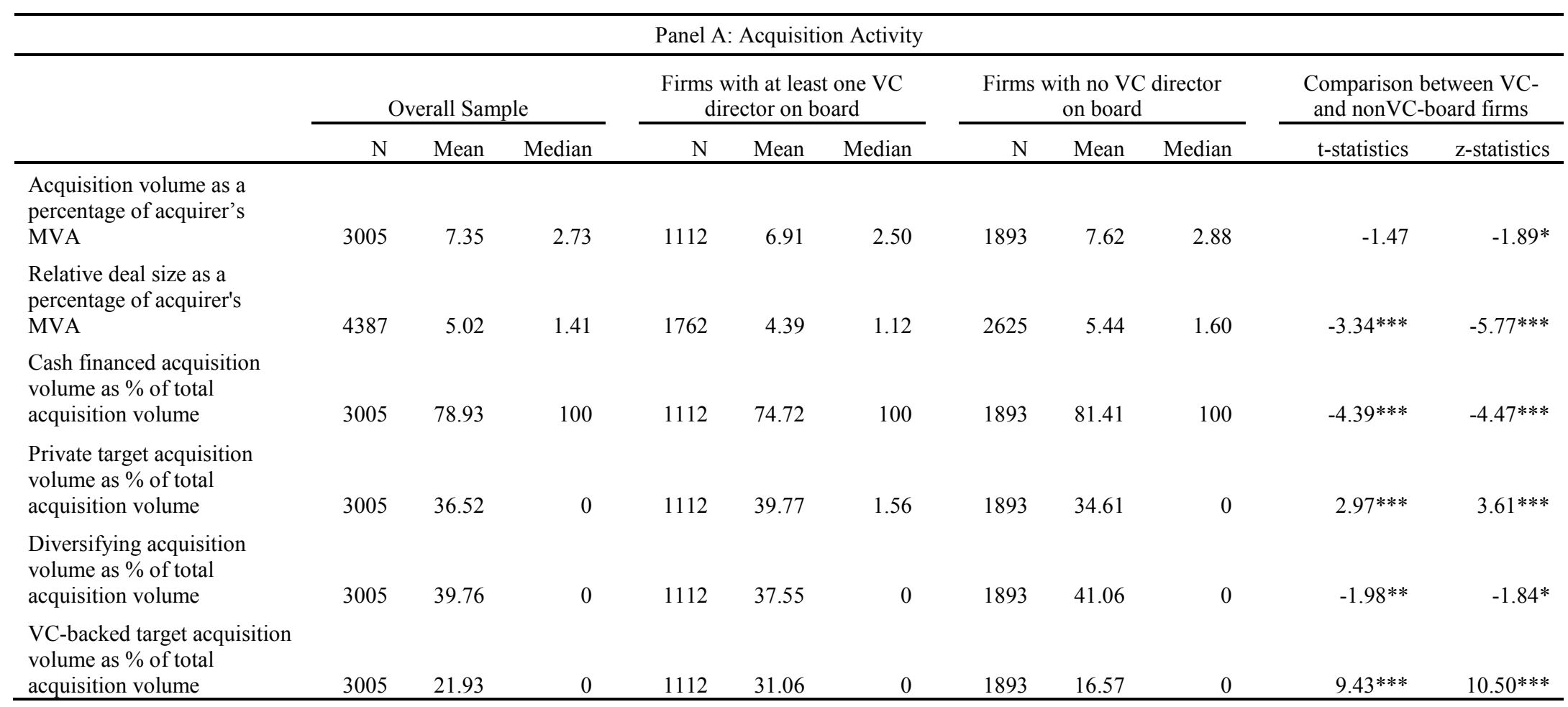


Panel B: Corporate Venture Capital (CVC) Investments

\begin{tabular}{|c|c|c|c|c|c|c|c|c|c|c|c|}
\hline & \multicolumn{3}{|c|}{ Overall Sample } & \multicolumn{3}{|c|}{$\begin{array}{c}\text { Firms with at least one VC } \\
\text { director on board }\end{array}$} & \multicolumn{3}{|c|}{$\begin{array}{c}\text { Firms with no VC director } \\
\text { on board }\end{array}$} & \multicolumn{2}{|c|}{$\begin{array}{l}\text { Comparison between VC- } \\
\text { and nonVC-board firms }\end{array}$} \\
\hline & $\mathrm{N}$ & Mean & Median & $\mathrm{N}$ & Mean & Median & $\mathrm{N}$ & Mean & Median & t-statistics & Z-statistics \\
\hline $\begin{array}{l}\text { Number of portfolio } \\
\text { companies for which the } \\
\text { firm provided CVC }\end{array}$ & 10118 & 0.33 & 0 & 3084 & 0.45 & 0 & 7034 & 0.27 & 0 & $2.42 * *$ & $11.72 * * *$ \\
\hline $\begin{array}{l}\text { Total CVC invested by the } \\
\text { firm's fund in the portfolio } \\
\text { companies (as a } \\
\text { percentage of its MVA) }\end{array}$ & 8507 & 0.01 & 0 & 2592 & 0.01 & 0 & 5915 & 0.00 & 0 & $5.86^{* * *}$ & $10.96^{* * *}$ \\
\hline $\begin{array}{l}\text { Total CVC under the } \\
\text { firm's management (as a } \\
\text { percentage of its MVA) }\end{array}$ & 8207 & 0.02 & 0 & 2415 & 0.03 & 0 & 5792 & 0.01 & 0 & $3.14 * * *$ & $3.75 * * *$ \\
\hline \multicolumn{12}{|c|}{ Panel C: Joint Ventures and Strategic Alliances } \\
\hline & \multicolumn{3}{|c|}{ Overall Sample } & \multicolumn{3}{|c|}{$\begin{array}{c}\text { Firms with at least one VC } \\
\text { director on board }\end{array}$} & \multicolumn{3}{|c|}{$\begin{array}{l}\text { Firms with no VC director } \\
\text { on board }\end{array}$} & \multicolumn{2}{|c|}{$\begin{array}{c}\text { Comparison between } \mathrm{VC} \text { - and } \\
\text { nonVC-board firms }\end{array}$} \\
\hline & $\mathrm{N}$ & Mean & Median & $\mathrm{N}$ & Mean & Median & $\mathrm{N}$ & Mean & Median & t-statistics & Z-statistics \\
\hline $\begin{array}{l}\text { Total number of joint } \\
\text { ventures } \\
\text { Total number of strategic }\end{array}$ & 10118 & 0.14 & 0 & 3084 & 0.15 & 0 & 7034 & 0.13 & 0 & 1.19 & 0.1502 \\
\hline alliances & 10118 & 0.66 & 0 & 3084 & 1.18 & 0 & 7034 & 0.43 & 0 & $9.06^{* * *}$ & $16.97 * * *$ \\
\hline
\end{tabular}




\section{Table 5. Regressions of R\&D outlays}

This table shows the results of the fixed effects regressions of the R\&D outlays of our sample of firms. The dependent variable is the R\&D outlay of the firms as a percentage of their market value of assets. $V C 1$ is a dummy variable that takes the value of 1 if the firm has one $\mathrm{VC}$ director on board and 0 otherwise, $V C 2$ takes the value of 1 if the firm has two directors on board and 0 otherwise, and $V C 3$ takes the value of 1 if the firm has three or more directors on board and 0 otherwise. Firm size is the natural logarithm of market value of assets, Tobin's $Q$ is the lagged ratio of market value of assets to book value of assets, Leverage is defined as interest bearing debt divided by operating assets, and Firm public age is the natural logarithm of the number of years since the firm's IPO. The regressions also include a constant term and year dummies which are not reported. Industry dummies are assigned according to the Fama-French 48 industry groups. For each independent variable, the first row reports its estimated coefficient and the second row the corresponding tstatistic. All standard errors are heteroskedasticity-robust and are clustered at the firm level. ***, **, and * indicate statistical significance at the $1 \%, 5 \%$ and $10 \%$ level, respectively.

\begin{tabular}{|c|c|c|c|c|}
\hline & \multicolumn{4}{|c|}{$\mathrm{R} \& \mathrm{D}$ as a percentage of firm size } \\
\hline & (I) & (II) & (III) & $(\mathrm{IV})$ \\
\hline \multirow[t]{2}{*}{$\mathrm{VC} 1$ (indicator) } & 0.231 & & 0.229 & \\
\hline & $2.11 * *$ & & $2.07 * *$ & \\
\hline \multirow[t]{2}{*}{$\mathrm{VC} 2$ (indicator) } & 0.524 & & 0.523 & \\
\hline & $2.19^{* *}$ & & $2.18^{* *}$ & \\
\hline \multirow[t]{2}{*}{ VC3 (indicator) } & 0.288 & & 0.284 & \\
\hline & 1.040 & & 1.030 & \\
\hline \multirow[t]{2}{*}{ Number of VC directors } & & 0.157 & & 0.154 \\
\hline & & $1.98 * *$ & & $1.94 * *$ \\
\hline \multirow[t]{2}{*}{ Number of independent directors } & 0.045 & 0.046 & 0.046 & 0.047 \\
\hline & $2.96^{* * *}$ & $3.03 * * *$ & $2.99 * * *$ & $3.06^{* * *}$ \\
\hline \multirow[t]{2}{*}{ Firm size } & -1.759 & -1.760 & -1.776 & -1.778 \\
\hline & $-12.7 * * *$ & $-12.7 * * *$ & $-12.73 * * *$ & $-12.73 * * *$ \\
\hline \multirow[t]{2}{*}{ Tobin's Q } & -0.014 & -0.014 & -0.014 & -0.014 \\
\hline & -0.960 & -0.940 & -0.920 & -0.900 \\
\hline \multirow[t]{2}{*}{ Leverage } & 0.211 & 0.210 & 0.222 & 0.221 \\
\hline & $2.21 * *$ & $2.19 * *$ & $2.27 * *$ & $2.25 * *$ \\
\hline \multirow[t]{2}{*}{ Firm public age } & 0.119 & 0.127 & 0.124 & 0.133 \\
\hline & 0.710 & 0.750 & 0.760 & 0.820 \\
\hline Firm fixed effects & Yes & Yes & Yes & Yes \\
\hline Industry fixed effects & No & No & Yes & Yes \\
\hline Year dummies & Yes & Yes & Yes & Yes \\
\hline Adjusted $\mathrm{R}^{2}$ & 0.1970 & 0.1963 & 0.1967 & 0.1959 \\
\hline Sample size & 8386 & 8386 & 8386 & 8386 \\
\hline
\end{tabular}




\section{Table 6. Determinants of the number of patents and citations}

Columns (I), (II) and (III) of this table present Poisson maximum likelihood estimates for the determinants of the adjusted number of patents, the adjusted number of citations and the adjusted number of citations per patent obtained by our sample of firms, respectively. The adjusted number of patents is obtained by dividing the number of patents for each firm by the mean of the number of patents in the same cohort to which the patent belongs, where the cohorts are constructed for each year and technology class defined by United States Patent and Trademark Office (USPTO). Similar adjustments are made for the number of citations and the number of citations per patent. The adjusted numbers are then rounded to the nearest integer for the Poisson model. Firm public age is the natural logarithm of the number of years since the firm's IPO, Firm size is the natural logarithm of market value of assets, and Tobin's $Q$ is the lagged ratio of market value of assets to book value of assets. The models also include a constant term which is not reported. For each independent variable, the first row reports its estimated coefficient and the second row the corresponding z-statistic. All standard errors are heteroskedasticity-robust and are clustered at the firm level. ${ }^{* *},{ }^{* *}$, and $*$ indicate statistical significance at the $1 \%, 5 \%$ and $10 \%$ level, respectively.

\begin{tabular}{|c|c|c|c|}
\hline & $\begin{array}{l}\text { Adjusted } \\
\text { Patents }\end{array}$ & $\begin{array}{l}\text { Adjusted } \\
\text { Citations }\end{array}$ & $\begin{array}{l}\text { Adjusted } \\
\text { Citations per } \\
\text { Patent }\end{array}$ \\
\hline & (I) & (II) & (III) \\
\hline \multirow[t]{2}{*}{ Number of VC directors } & -1.204 & -1.505 & -0.503 \\
\hline & -1.49 & -1.56 & -1.31 \\
\hline \multirow[t]{2}{*}{ Number of independent directors } & 0.038 & -0.011 & -0.011 \\
\hline & 0.76 & -0.18 & -0.39 \\
\hline \multirow[t]{2}{*}{ R\&D normalized by firm size } & 18.702 & 19.742 & 4.921 \\
\hline & $4.95 * * *$ & $4.24 * * *$ & $2.60 * * *$ \\
\hline \multirow[t]{2}{*}{ No of VC dirs * normalized R\&D } & -0.024 & 0.802 & 3.749 \\
\hline & -0.01 & 0.18 & $1.72 *$ \\
\hline \multirow[t]{2}{*}{ Firm public age } & -0.358 & -0.418 & -0.316 \\
\hline & -1.49 & -1.4 & $-1.78 *$ \\
\hline \multirow[t]{2}{*}{ No of VC dirs * firm public age } & 0.362 & 0.407 & 0.089 \\
\hline & $1.67 *$ & $1.65^{*}$ & 0.87 \\
\hline \multirow[t]{2}{*}{ Acquisition volume normalized by firm size } & 0.652 & -0.592 & -0.531 \\
\hline & 1.29 & -0.67 & -1.03 \\
\hline \multirow[t]{2}{*}{ No of $\mathrm{VC}$ dirs * normalized acquisition volume } & -1.070 & -0.195 & 0.304 \\
\hline & -1.15 & -0.19 & 0.50 \\
\hline \multirow[t]{2}{*}{ CVC volume normalized by firm size } & -0.085 & -0.586 & 2.077 \\
\hline & -0.09 & -0.52 & $3.81 * * *$ \\
\hline \multirow[t]{2}{*}{ No of VC dirs * normalized CVC volume } & -0.645 & -0.584 & -1.471 \\
\hline & -1.07 & -0.83 & $-4.18 * * *$ \\
\hline \multirow[t]{2}{*}{ Firm size } & 0.645 & 0.678 & 0.226 \\
\hline & $6.33 * * *$ & $6.68 * * *$ & $5.74 * * *$ \\
\hline \multirow[t]{2}{*}{ Tobin's Q } & -0.037 & -0.024 & -0.034 \\
\hline & -0.82 & -0.47 & -1.1 \\
\hline Pseudo $\mathrm{R}^{2}$ & 0.3699 & 0.3240 & 0.0678 \\
\hline Sample Size & 1040 & 1040 & 1040 \\
\hline
\end{tabular}




\section{Table 7. Effect of VC directors on a public firm's acquisition strategy}

This table presents estimates of the models for the acquisition activity of our sample of public firms. Models (I) through (VII) show the results of the fixed effects regressions of the acquisition volumes. Columns (I) to (IV) have the acquisition volume of the firms as a percentage of their market value of assets as the dependent variable. Columns (V) to (VII) have the percentage of the total acquisition volume invested in the given types of acquisitions as the dependent variable. Columns (VIII) and (IX) present logit estimates for the probability of a firm in our sample to acquire a VC-backed target in an M\&A, where the dependent variable takes the value of one if the target firm acquired is VC-backed and zero otherwise. Column (X) shows OLS estimates for the target firm's R\&D outlays in an M\&A, where the dependent variable is the target firm's R\&D in an acquisition. $V C 1$ is a dummy variable that takes the value of 1 if the firm has one $\mathrm{VC}$ director on board and 0 otherwise, $V C 2$ takes the value of 1 if the firm has two directors on board and 0 otherwise, and $V C 3$ takes the value of 1 if the firm has three or more directors on board and 0 otherwise. Firm size is the natural logarithm of market value of assets, Tobin's $Q$ is the lagged ratio of market value of assets to book value of assets, Leverage is defined as interest bearing debt divided by operating assets, Firm public age is the natural logarithm of the number of years since the firm's IPO, and Director ownership is the proportion of shares owned by all directors of the firm. Normalized $R \& D$ is the acquiring firm's R\&D normalized by its size. Private target is a dummy variable that takes the value of 1 if the firm acquires a private target and 0 otherwise. Diversifying acquistion is a dummy variable that takes the value of 1 if the acquirer and the target are not in the same Fama-French 48 industry group and 0 otherwise. All models also include a constant term and year dummies which are not reported. Industry dummies are assigned according to the Fama-French 48 industry groups. For each independent variable, the first row reports its estimated coefficient and the second row the corresponding t- or zstatistic. All standard errors are heteroskedasticity-robust and are clustered at the firm level. ***, **, and * indicate statistical significance at the $1 \%, 5 \%$ and $10 \%$ level, respectively.

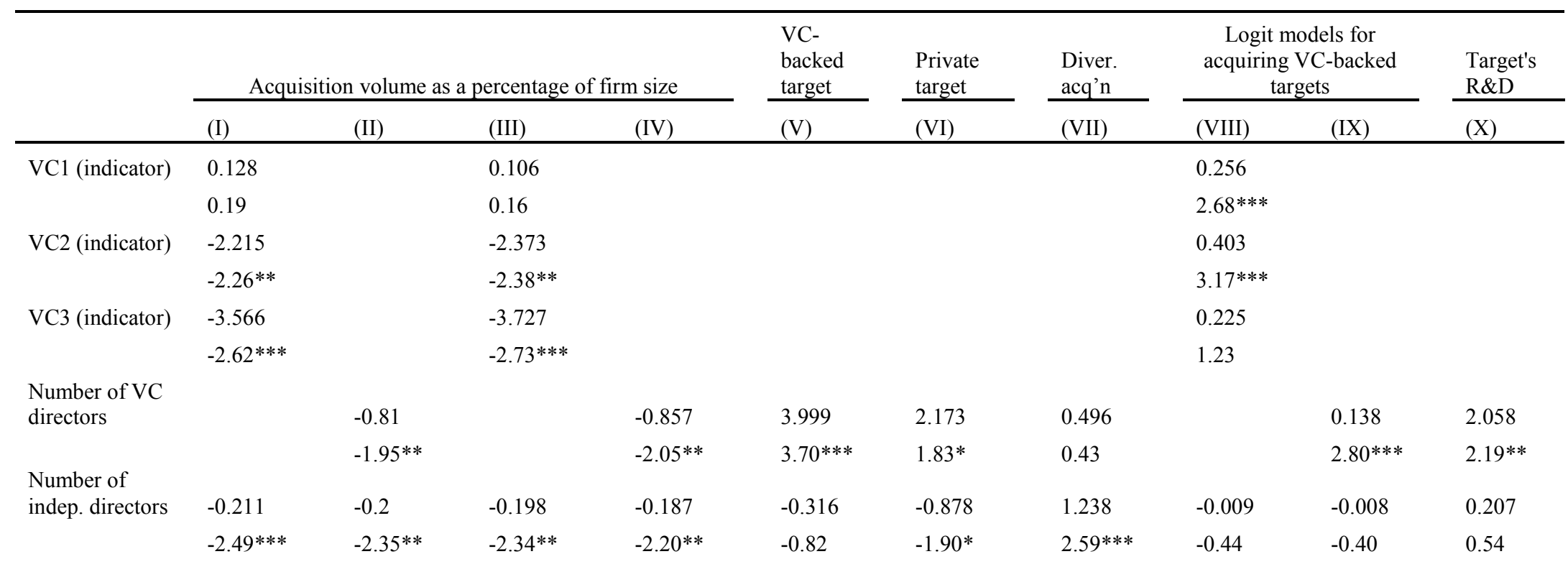




\begin{tabular}{|c|c|c|c|c|c|c|c|c|c|c|}
\hline Firm size & -0.044 & -0.034 & -0.048 & -0.038 & 2.22 & -6.46 & -0.376 & 0.248 & 0.249 & 0.073 \\
\hline & -0.1 & -0.07 & -0.11 & -0.08 & $4.02 * * *$ & $-9.58 * * *$ & -0.56 & $7.94 * * *$ & $8.26 * * *$ & 0.14 \\
\hline Tobin's Q & 0.411 & 0.414 & 0.411 & 0.413 & 0.989 & 1.684 & -0.248 & 0.010 & 0.012 & -0.196 \\
\hline & $1.81^{*}$ & $1.82 *$ & $1.80^{*}$ & $1.82 *$ & $2.99^{* * *}$ & $2.81^{* * *}$ & -0.75 & 1.34 & 1.50 & -1.50 \\
\hline Leverage & 0.46 & 0.466 & 0.392 & 0.401 & -2.45 & -4.845 & 0.021 & 0.023 & 0.023 & 0.145 \\
\hline & 0.69 & 0.7 & 0.58 & 0.58 & -0.63 & -1.09 & 0.01 & 1.09 & 1.12 & 0.04 \\
\hline Firm public age & 0.902 & 0.931 & 0.94 & 0.961 & -1.553 & 0.742 & 0.316 & -0.085 & -0.089 & -4.407 \\
\hline & 1.52 & 1.56 & 1.56 & 1.58 & -1.58 & 0.62 & 0.25 & -1.39 & -1.44 & $-3.18^{* * *}$ \\
\hline $\begin{array}{l}\text { Director } \\
\text { ownership }\end{array}$ & & & & & -9.791 & -2.842 & -0.368 & & & \\
\hline & & & & & $-2.14 * *$ & -0.51 & -0.06 & & & \\
\hline $\begin{array}{l}\text { Normalized } \\
\text { R\&D }\end{array}$ & & & & & & & & 11.217 & 11.385 & 1.003 \\
\hline & & & & & & & & $7.02 * * *$ & $7.19^{* * *}$ & $2.85^{* * *}$ \\
\hline $\begin{array}{l}\text { Private target } \\
\text { (indicator) }\end{array}$ & & & & & & & & 0.375 & 0.368 & -1.388 \\
\hline$A$ & & & & & & & & $5.66 * * *$ & $5.57 * * *$ & -0.43 \\
\hline $\begin{array}{l}\text { Diversifying } \\
\text { acquisition } \\
\text { (indicator) }\end{array}$ & & & & & & & & & & \\
\hline & & & & & & & & 0.110 & 0.111 & 0.373 \\
\hline & & & & & & & & 1.59 & 1.61 & 0.24 \\
\hline $\begin{array}{l}\text { Firm fixed } \\
\text { effects }\end{array}$ & Yes & Yes & Yes & Yes & No & No & No & No & No & No \\
\hline $\begin{array}{l}\text { Industry fixed } \\
\text { effects }\end{array}$ & No & No & Yes & Yes & Yes & Yes & Yes & Yes & Yes & Yes \\
\hline Year dummies & Yes & Yes & Yes & Yes & Yes & Yes & Yes & Yes & Yes & Yes \\
\hline $\begin{array}{l}\text { Adjusted } R^{2} / \\
\text { Pseudo } R^{2}\end{array}$ & 0.0101 & 0.0093 & 0.0097 & 0.0089 & 0.1311 & 0.1059 & 0.1218 & 0.1281 & 0.1272 & 0.1314 \\
\hline Sample size & 8393 & 8393 & 8393 & 8393 & 2685 & 2685 & 2685 & 8297 & 8297 & 224 \\
\hline
\end{tabular}




\section{Table 8. Effect of VC directors on a public firm's strategic partnerships}

This table presents estimates of the models for the strategic relationships formed by our sample of public firms. Models (I) through (IV) show Poisson maximum likelihood estimates for the determinants of the number of joint ventures (JVs) and strategic alliances. Columns (I) and (II) have the number of JVs as the dependent variable, and columns (III) and (IV) have the number of strategic alliances as the dependent variable. Models (V) through (VII) show logit estimates for the probability to collaborate with VC-backed partners in joint ventures (JVs) or strategic alliances. In columns (V) and (VI), the dependent variable takes the value of one if the partner firm in the JV is VC-backed and zero otherwise, and in column (VII) the dependent variable takes the value of one if the partner firm in the alliance is VC-backed and zero otherwise. $V C l$ is a dummy variable that takes the value of 1 if the firm has one $\mathrm{VC}$ director on board and 0 otherwise, $V C 2$ takes the value of 1 if the firm has two directors on board and 0 otherwise, and $V C 3$ takes the value of 1 if the firm has three or more directors on board and 0 otherwise. Firm size is the natural logarithm of market value of assets, Tobin's $Q$ is the lagged ratio of market value of assets to book value of assets, Leverage is defined as interest bearing debt divided by operating assets, Firm public age is the natural logarithm of the number of years since the firm's IPO, Director ownership is the proportion of shares owned by all directors of the firm, and Operating cash flow is sales minus the cost of goods sold and selling, general and administrative expenses. Diversifying JV/alliance is a dummy variable that takes the value of 1 if the participating firms are not in the same Fama-French 48 industry group. The models also include a constant term and year dummies which are not reported. Industry dummies are assigned according to the Fama-French 48 industry groups. For each independent variable, the first row reports its estimated coefficient and the second row the corresponding z-statistic. All standard errors are heteroskedasticity-robust and are clustered at the firm level. ${ }^{* * *},{ }^{* *}$, and ${ }^{*}$ indicate statistical significance at the $1 \%, 5 \%$ and $10 \%$ level, respectively.

\begin{tabular}{|c|c|c|c|c|c|c|c|}
\hline & \multicolumn{4}{|c|}{ Poisson Models } & \multicolumn{3}{|c|}{ Logit Models } \\
\hline & \multicolumn{2}{|c|}{$\begin{array}{c}\text { Number of } \\
\text { Joint Ventures }\end{array}$} & \multicolumn{2}{|c|}{$\begin{array}{c}\text { Number of } \\
\text { Strategic Alliances } \\
\end{array}$} & \multicolumn{2}{|c|}{$\begin{array}{l}\text { VC-Backed } \\
\text { JV Partners } \\
\end{array}$} & \multirow{2}{*}{$\begin{array}{c}\text { VC-backed } \\
\text { Alliance } \\
\text { Partners } \\
\text { (VII) }\end{array}$} \\
\hline & (I) & (II) & (III) & (IV) & $(\mathrm{V})$ & $(\mathrm{VI})$ & \\
\hline \multirow[t]{2}{*}{$\mathrm{VC1}$ (indicator) } & 0.070 & & 0.120 & & 0.034 & & \\
\hline & 0.39 & & $1.93 * *$ & & 0.08 & & \\
\hline \multirow[t]{2}{*}{ VC2 (indicator) } & 0.797 & & 0.363 & & 1.418 & & \\
\hline & $2.13 * *$ & & $3.15^{* * *}$ & & $1.90^{*}$ & & \\
\hline \multirow[t]{2}{*}{ VC3 (indicator) } & 1.513 & & 0.334 & & 0.937 & & \\
\hline & $3.06^{* * *}$ & & $2.17 * *$ & & $1.71^{*}$ & & \\
\hline \multirow[t]{2}{*}{ Number of VC directors } & & 0.326 & & 0.115 & & 0.377 & -0.004 \\
\hline & & $2.37^{* *}$ & & $2.52 * * *$ & & $2.41^{* *}$ & -0.1 \\
\hline \multirow[t]{2}{*}{ Number of independent directors } & 0.035 & 0.029 & -0.010 & -0.008 & -0.029 & -0.022 & -0.029 \\
\hline & 1.16 & 0.95 & -0.73 & -0.59 & -0.44 & -0.33 & -1.48 \\
\hline
\end{tabular}




\begin{tabular}{|c|c|c|c|c|c|c|c|c|}
\hline & $R \& D$ normalized by firm size & 12.720 & 12.585 & 3.877 & 3.984 & 4.725 & 5.237 & 2.836 \\
\hline & & $3.02^{* * *}$ & $2.99 * * *$ & $2.74 * * *$ & $2.82 * * *$ & 0.82 & 0.92 & $2.05^{* *}$ \\
\hline & $\begin{array}{l}\text { No of VC dirs } \\
* \text { normalized R\&D }\end{array}$ & -11.291 & -10.590 & 0.090 & 0.300 & & & \\
\hline & & $-3.85 * * *$ & $-3.65 * * *$ & 0.11 & 0.37 & & & \\
\hline & Firm size & 0.264 & 0.300 & 0.224 & 0.226 & 0.174 & 0.165 & 0.094 \\
\hline & & $2.08^{* *}$ & $2.42 * *$ & $4.84^{* * *}$ & $4.89^{* * *}$ & 1.44 & 1.45 & $3.92^{* * *}$ \\
\hline & Tobin's Q & 0.059 & 0.058 & 0.003 & 0.003 & -0.113 & -0.087 & -0.021 \\
\hline & & $2.26^{* *}$ & $2.21 * *$ & 0.65 & 0.76 & $-1.65^{*}$ & -1.49 & $-2.8^{* * *}$ \\
\hline & Leverage & -0.211 & -0.223 & -0.001 & -0.011 & 0.352 & 0.587 & -0.070 \\
\hline & & -1.6 & $-1.69^{*}$ & -0.02 & -0.16 & 0.62 & 0.91 & -0.46 \\
\hline & Firm public age & 0.306 & 0.261 & 0.156 & 0.137 & 0.030 & 0.005 & 0.025 \\
\hline & & 1.26 & 1.09 & 1.43 & 1.27 & 0.15 & 0.03 & 0.51 \\
\hline & Director ownership & -1.503 & -1.539 & 0.210 & 0.198 & & & \\
\hline & & -1.45 & -1.49 & 0.74 & 0.70 & & & \\
\hline & Operating cash flow & -2.689 & -2.364 & 1.143 & 0.940 & & & \\
\hline & & $-1.89 *$ & $-1.68^{*}$ & $2.00^{* *}$ & $1.66^{*}$ & & & \\
\hline & (indicator) & & & & & 0.224 & 0.289 & -0.305 \\
\hline & & & & & & 0.68 & 0.91 & $-4.16^{* * *}$ \\
\hline & Firm Fixed Effects & Yes & Yes & Yes & Yes & No & No & No \\
\hline & Industry Fixed Effects & No & No & No & No & Yes & Yes & Yes \\
\hline & Year Dummies & Yes & Yes & Yes & Yes & Yes & Yes & Yes \\
\hline & Pseudo $\mathrm{R}^{2}$ & 0.6849 & 0.6841 & 0.5870 & 0.5868 & 0.1538 & 0.1480 & 0.0639 \\
\hline & Sample Size & 2432 & 2432 & 4587 & 4587 & 386 & 386 & 3658 \\
\hline
\end{tabular}




\section{Table 9. Determinants of the VC director appointments and departures}

This table presents the results of the logit models of the probability of a VC director to be appointed to the board and the probability of a VC director to depart from the board of our sample of firms. In columns (I) and (II), the dependent variable takes the value of one if at least one VC director is appointed to the board and zero if any director other than a $\mathrm{VC}$ is appointed to the board. In columns (III) and (IV), the dependent variable takes the value of one if a $\mathrm{VC}$ director departs from the board and zero if any director other than a VC departs from the board. Director age is the age of the appointed/departing director's age, Number of other directorships is the number of other directorships held by the appointed/departing director, Female is a dummy variable that takes the value of 1 if the appointed/departing director is a female and 0 otherwise, Director ownership is the proportion of shares owned by all directors of the firm, Firm public age is the natural logarithm of the number of years since the firm's IPO, Firm size is the natural logarithm of market value of assets, Number of joint ventures with VC-backed firms (Number of strategic alliances with VCbacked firms) is the number of joint ventures (strategic alliances) formed by the firm with VC-backed firms, Sales growth is the difference between the current sales and the lagged sales normalized by lagged sales, and Stock return is the buy-and-hold return over the fiscal year. The models also include year and industry dummies which are not reported. Industries are classified according to the Fama-French 48 industry groups. For each independent variable, the first row reports its estimated coefficient and the second row the corresponding z-statistic. All standard errors are heteroskedasticity-robust and are clustered at the firm level. $* * *, * *$, and $*$ indicate statistical significance at the $1 \%, 5 \%$ and $10 \%$ level, respectively.

\begin{tabular}{|c|c|c|c|c|}
\hline & \multicolumn{2}{|c|}{ VC Director Appointment } & \multicolumn{2}{|c|}{ VC Director Departure } \\
\hline & (I) & (II) & (III) & (IV) \\
\hline \multirow[t]{2}{*}{ Director age } & -0.030 & -0.031 & -0.041 & -0.062 \\
\hline & $-2.54 * * *$ & $-1.84 *$ & $-4.18 * * *$ & $-3.69 * * *$ \\
\hline \multirow[t]{2}{*}{ Number of other boards served } & 0.209 & 0.219 & 0.342 & 0.495 \\
\hline & $3.59 * * *$ & $2.42 * *$ & $7.04 * * *$ & $5.24 * * *$ \\
\hline \multirow[t]{2}{*}{ Female (indicator) } & -0.261 & -0.380 & -1.455 & -1.546 \\
\hline & -0.99 & -1.12 & $-3.42 * * *$ & $-3.00 * * *$ \\
\hline \multirow[t]{2}{*}{ Number of independent directors } & 0.058 & -0.036 & 0.045 & -0.238 \\
\hline & 0.97 & -0.26 & 0.76 & -1.52 \\
\hline \multirow[t]{2}{*}{ Board size } & -0.865 & -0.258 & -0.332 & 3.087 \\
\hline & $-1.80 *$ & -0.18 & -0.65 & $2.11 * *$ \\
\hline \multirow[t]{2}{*}{ Director ownership } & 1.027 & -0.566 & 0.088 & -6.568 \\
\hline & $2.67 * * *$ & -0.33 & 0.14 & $-2.02 * *$ \\
\hline \multirow[t]{2}{*}{ Firm public age } & -0.056 & 0.505 & -0.310 & -0.757 \\
\hline & -0.45 & 0.37 & $-2.90 * * *$ & -0.50 \\
\hline \multirow[t]{2}{*}{ Firm size } & 0.141 & -0.174 & 0.102 & -0.420 \\
\hline & $2.03 * *$ & -0.41 & 1.48 & -0.84 \\
\hline \multirow[t]{2}{*}{ R\&D (normalized by firm size) } & 6.951 & -1.418 & 10.775 & 1.301 \\
\hline & $2.72 * * *$ & -0.11 & $4.99 * * *$ & 0.15 \\
\hline \multirow[t]{2}{*}{ CAPEX (normalized by firm size) } & -0.156 & 4.372 & -11.352 & -20.351 \\
\hline & -0.05 & 0.55 & $-2.63 * * *$ & $-2.69 * * *$ \\
\hline \multirow[t]{2}{*}{$\begin{array}{l}\text { Acquisition volume of VC-backed targets } \\
\text { (normalized by firm size) }\end{array}$} & 0.010 & 0.015 & 0.019 & -0.008 \\
\hline & 1.49 & 0.81 & $1.92 *$ & -0.38 \\
\hline
\end{tabular}




\begin{tabular}{lllll} 
Number of joint ventures with VC-backed & & & -0.069 \\
firms & 0.365 & 1.567 & 0.205 & -0.15 \\
& 0.68 & 1.49 & 0.61 & 0.217 \\
$\begin{array}{l}\text { Number of strategic alliances with VC- } \\
\text { backed firms }\end{array}$ & -0.047 & 0.135 & 0.054 & $1.79 *$ \\
& -0.76 & 1.05 & 1.15 & -0.133 \\
Sales growth & 0.104 & 0.228 & -0.179 & -0.35 \\
& 0.36 & 0.39 & -0.48 & 0.037 \\
Stock return & 0.029 & -0.021 & -0.053 & 0.42 \\
& 0.18 & -0.07 & -0.32 & Yes \\
& & & & No \\
Firm Fixed Effects & No & Yes & No & Yes \\
Industry Fixed Effects & Yes & No & Yes & 0.2016 \\
Year Dummies & Yes & Yes & Yes & 912 \\
Pseudo R & 0.0670 & 0.0913 & 0.1302 & 4510 \\
Sample Size & 5212 & 884 & & \\
\hline
\end{tabular}


Figure 1. Number of sample firms over time

This figure shows the number of public firms available in the IRRC database from 1998 to 2006 excluding utility companies and financial companies. The firms are split into four groups according to the number of VC directors on board. Directors who are partners or executives of a venture capital firm are denoted as VC directors.

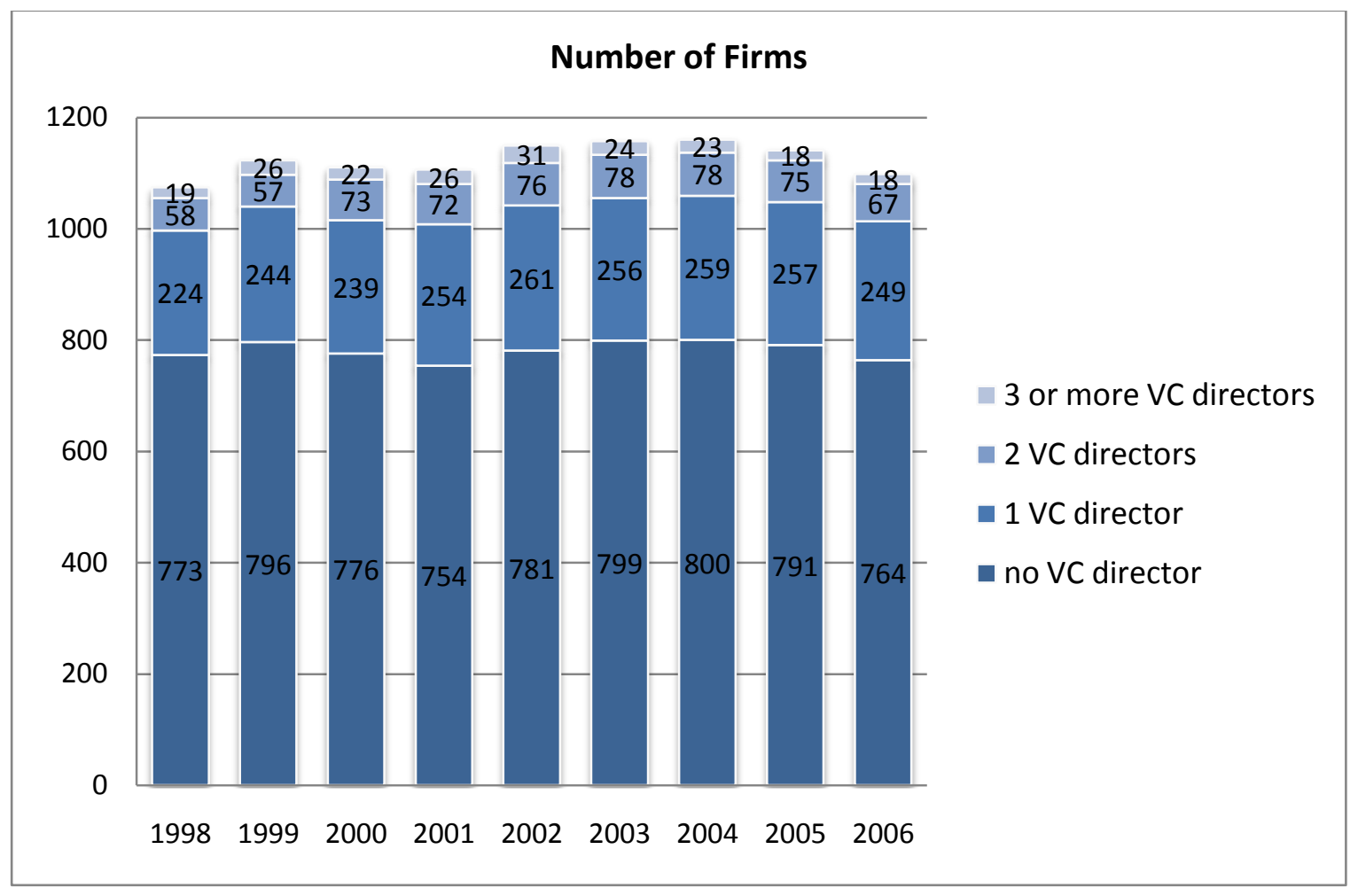


Figure 2. Tobin's Q, R\&D and CAPEX

This figure shows Tobin's $Q, R \& D$ and CAPEX (both given as a percentage of market value of assets (MVA)) as a function of the number of $\mathrm{VC}$ directors on board for our sample of public firms.
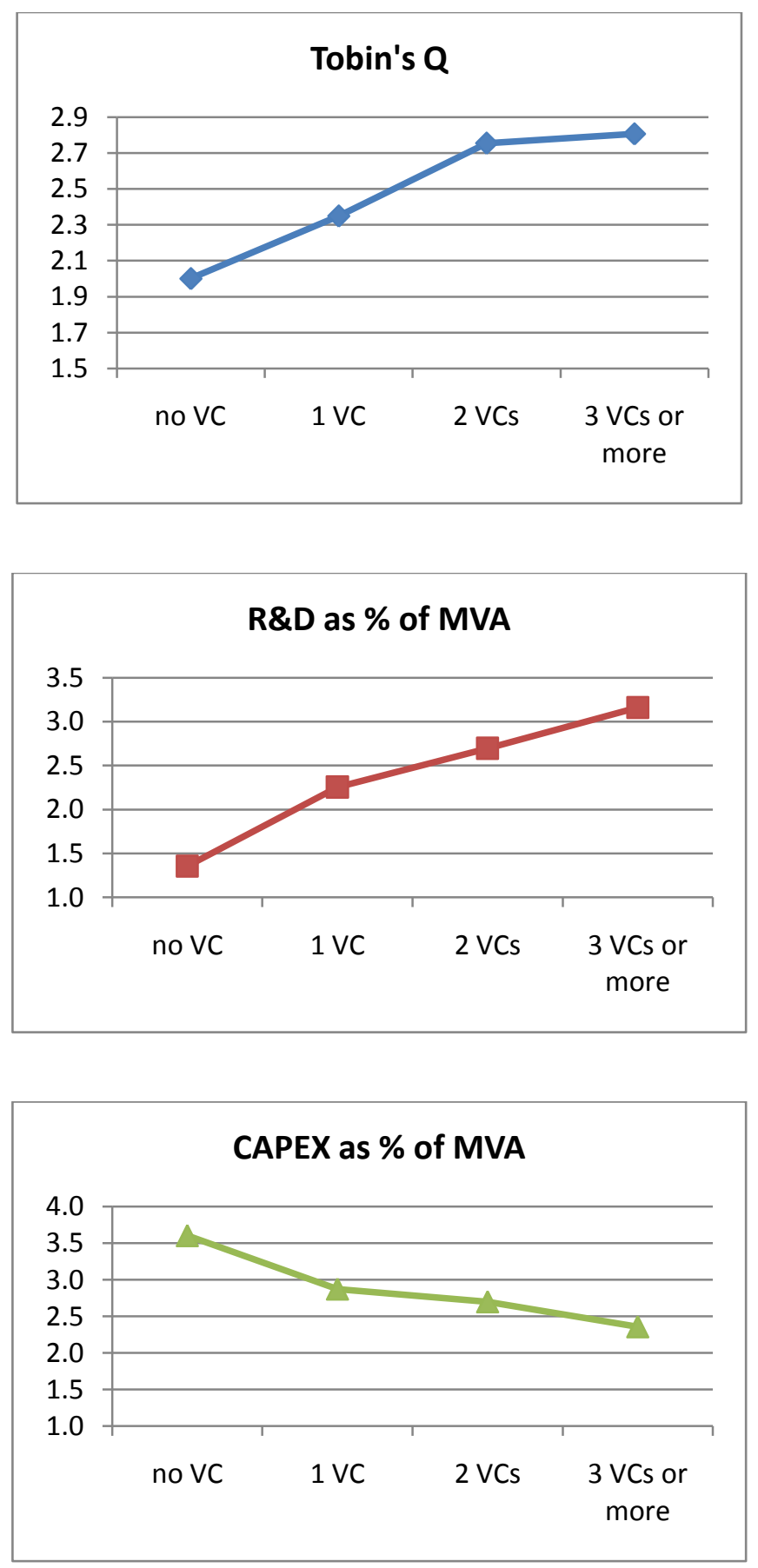


\section{REFERENCES}

Baker, M.P., and P.A. Gompers, 2003, "The Determinants of Board Structure at the Initial Public Offering", Journal of Law and Economics, 46, 569-598.

Barry, C.B., Muscarella, C.J., Peavy III, J.W., and M.R.Vetsuypens, 1990, “The Role of Venture Capital in the Creation of Public Companies: Evidence from the Going-Public Process", Journal of Financial Economics, 27, 447-471.

Brav, A., and P.A. Gompers, 1997, "Myth or Reality? The Long-Run Underperformance of Initial Public Offerings: Evidence from Venture and Nonventure Capital-Backed Companies", Journal of Finance, 52, 1791-1821.

Chesbrough, H., 2002, "Making Sense of Corporate Venture Capital", Harvard Business Review, March 2002.

Dushnitsky, G., and M.J. Lenox, 2005, "When do Incumbents Learn From Entrepreneurial Ventures?”, Research Policy, 34, 615-639.

Dushnitsky, G., and M.J. Lenox, 2006, “When does Corporate Venture Capital Investment Create Firm Value?”, Journal of Business Venturing, 21, 753-772.

Fama, E.F., and K.R. French, 1997, "Industry Costs of Equity”, Journal of Financial Economics, 43, 153-193.

Gompers, P.A., 1995, “Optimal Investment, Monitoring, and the Staging of Venture Capital”, Journal of Finance, 50, 1461-1489.

Gompers, P.A., and Y. Xuan, 2006, "The Role of Venture Capitalists in the Acquisition of Private Companies", working paper, Harvard Business School.

Gompers, P.A., and Y. Xuan, 2008, "Bridge Building in Venture Capital-Backed Acquisitions", working paper, Harvard Business School.

Griliches, Z., 1990, “Patent Statistics as Economic Indicators: A Survey”, Journal of Economic Literature, 28, 1661-1707.

Hall, B.H., Jaffe, A.B., and M. Trajtenberg, 2001, "The NBER Patent Citations Data File: Lessons, Insights and Methodological Tools", working paper, NBER.

Hall, B.H., Jaffe, A.B., and M. Trajtenberg, 2005, "Market Value and Patent Citations", RAND Journal of Economics, 36, 16-38.

Hellmann, T., and M. Puri, 2000, “The Interaction between Product Market and Financing Strategy: The Role of Venture Capital”, Review of Financial Studies, 13, 959-984. 
Hellmann, T., and M. Puri, 2002, "Venture Capital and the Professionalization of Start-Up Firms: Empirical Evidence", Journal of Finance, 57, 169-197.

Hochberg, Y.V., 2008, "Venture Capital and Corporate Governance in the Newly Public Firm", working paper, Northwestern University.

Hsu, D.H., 2004, “What do Entrepreneurs Pay for Venture Capital Affiliation?”, Journal of Finance, 59, 1805-1844.

Jain, B.A., and O. Kini, 2000, "Does the Presence of Venture Capitalists Improve the Survival Profile of IPO Firms?”, Journal of Business Finance \& Accounting, 27, 1139-1183.

Kaplan, S.N., and P. Stromberg, 2003, "Financial Contracting Theory Meets the Real World: Evidence From Venture Capital Contracts", Review of Economic Studies, 70, 281-316.

Kaplan, S.N., and P. Stromberg, 2004, "Characteristics, Contracts, and Actions: Evidence From Venture Capitalist Analyses”, Journal of Finance, 59, 2173-2206.

Kortum, S., and J. Lerner, 2000, "Assessing the Contribution of Venture Capital to Innovation”, RAND Journal of Economics, 31, 674-692.

Lindsey, L., 2008, "Blurring Firm Boundaries: The Role of Venture Capital in Strategic Alliances," Journal of Finance, 63, 1137-1168.

Lee, P.M., and S. Wahal, 2004, "Grandstanding, Certification and the Underpricing of Venture Capital Backed IPOs", Journal of Financial Economics, 73, 375-407.

Lerner, J., 1994, “The Syndication of Venture Capital Investments”, Financial Management, $23,16-27$.

Lerner, J., 1995, "Venture Capitalists and the Oversight of Private Firms", Journal of Finance, 50, 301-318.

Lerner, J., Sorensen, M., and P. Stromberg, 2008, "Private Equity and Long-Run Investment: The Case of Innovation", working paper, Harvard Business School.

Megginson, W.L., and K. Weiss, 1991, "Venture Capitalist Certification in Initial Public Offerings", Journal of Finance, 46, 879-903.

Robinson, D.T., and T. Stuart, 2007, "Network Effects in the Governance of Strategic Alliances", Journal of Law, Economics, and Organization, 23, 242-273.

Trajtenberg, M., 1990, “A Penny for your Quotes: Patent Citations and the Value of Information”, RAND Journal of Economics, 21, 325-342. 